\title{
Chemical characterization and sources of submicron aerosols in the northeastern Qinghai-Tibet Plateau: insights from high-resolution mass spectrometry
}

\author{
Xinghua Zhang ${ }^{1,2,3}$, Jianzhong Xu ${ }^{1}$, Shichang Kang ${ }^{1}$, Qi Zhang ${ }^{4}$, and Junying Sun $^{5}$ \\ ${ }^{1}$ State Key Laboratory of Cryospheric Sciences, Northwest Institute of Eco-Environment and Resources, \\ Chinese Academy of Sciences, Lanzhou 730000, China \\ ${ }^{2}$ Key Laboratory of Arid Climatic Change and Reducing Disaster of Gansu Province, Key Laboratory of Arid Climatic \\ Change and Disaster Reduction of CMA, Institute of Arid Meteorology, China Meteorological Administration, \\ Lanzhou 730020, China \\ ${ }^{3}$ University of Chinese Academy of Sciences, Beijing 100049, China \\ ${ }^{4}$ Department of Environmental Toxicology, University of California, Davis, CA 95616, USA \\ ${ }^{5}$ Chinese Academy of Meteorological Sciences, China Meteorological Administration, Beijing 100081, China
}

Correspondence: Jianzhong Xu (jzxu@ @ lzb.ac.cn)

Received: 29 January 2019 - Discussion started: 22 February 2019

Revised: 15 May 2019 - Accepted: 20 May 2019 - Published: 13 June 2019

\begin{abstract}
An Aerodyne high-resolution time-of-flight aerosol mass spectrometer (HR-ToF-AMS) was deployed along with other online instruments to study the highly time resolved chemistry and sources of submicron aerosols $\left(\mathrm{PM}_{1}\right)$ at Waliguan (WLG) Baseline Observatory, a highaltitude (3816 ma.s.l.) background station located at the northeast edge of the Qinghai-Tibet Plateau (QTP), during 1-31 July 2017. The average $\mathrm{PM}_{1}$ mass concentration during this study was $9.1 \mu \mathrm{g} \mathrm{m}^{-3}$ (ranging from 0.3 to $28.1 \mu \mathrm{g} \mathrm{m}^{-3}$ ), which was distinctly higher than those (2.0$5.7 \mu \mathrm{g} \mathrm{m}^{-3}$ ) measured with the Aerodyne AMS at other high-elevation sites in the southern or central QTP. Sulfate showed a dominant contribution $(38.1 \%)$ to $\mathrm{PM}_{1}$ at WLG followed by organics (34.5\%), ammonium (15.2\%), nitrate $(8.1 \%), \mathrm{BC}(3.0 \%)$ and chloride $(1.1 \%)$. Accordingly, bulk aerosols appeared to be slightly acidic throughout this study, mainly related to the enhanced sulfate contribution. All chemical species peaked at the accumulation mode, indicating the well-mixed and highly aged aerosol particles at WLG from long-range transport. Positive matrix factorization (PMF) on the high-resolution organic mass spectra resolved four distinct organic aerosol (OA) components, including a traffic-related hydrocarbon-like OA (HOA), a relatively fresh biomass burning OA (BBOA), an aged biomass burning $\mathrm{OA}(\mathrm{agBBOA})$ and a more-oxidized oxygenated
\end{abstract}

OA (OOA). On average, the two relatively oxidized OAs, OOA and agBBOA, contributed $34.4 \%$ and $40.4 \%$ of organics, respectively, while the rest were $18.4 \%$ for BBOA and $6.8 \%$ for HOA. Source analysis for air masses showed that higher mass concentrations of $\mathrm{PM}_{1}$ and enhanced contributions of sulfate and biomass-burning-related OA components $(\operatorname{agBBOA}+\mathrm{BBOA})$ were from the northeast of the WLG with shorter transport distance, whereas lower $\mathrm{PM}_{1}$ mass concentrations with enhanced OOA contribution were from the west after long-range transport, suggesting their distinct aerosol sources and significant impacts of regional transport on aerosol mass loadings and chemistry at WLG.

\section{Introduction}

The Qinghai-Tibet Plateau (QTP) is one of the most remote and pristine regions in the world. Its huge surface area $\left(\sim 2500000 \mathrm{~km}^{2}\right)$ and high elevation (with a mean elevation of more than $4000 \mathrm{~m}$ above sea level; a.s.l.) make it especially important in earth sciences, and therefore the QTP is generally called as the "third pole" (Yao et al., 2012). According to its high elevation, sparse population and minor local anthropogenic activities, the QTP is regarded as an ideal 
area for observing the natural background aerosol and longrange-transported aerosol. In recent decades, a certain number of studies have presented convincing evidence for the long-range transport of air pollutants from the surrounding areas to the QTP (Engling et al., 2011; Xia et al., 2011; Lüthi et al., 2015; Zhang et al., 2017). Particularly, air pollutants from southern and southeastern Asia, two of the major regions with enhanced biomass burning emissions in the world, stacked up in the southern foothills of the Himalayas during the pre-monsoon season, then climbed over the Himalayas using topographic lifting and the mountain-valley breeze circulation, and finally moved upward to the QTP (Lüthi et al., 2015). These long-range transports followed by deposition of polluted air masses, especially for the two important lightabsorbing substances of black carbon (BC) and brown carbon $(\mathrm{BrC})$, have significant impacts on climate, the environment and hydrology in the QTP (Xu et al., 2009; Kang et al., 2010; Qian et al., 2011; Yang et al., 2014).

In contrast, aerosol particles in the northern QTP showed quite different behaviors compared to those in the southern QTP due to the different aerosol sources and climate for these two regions. For example, Li et al. (2016) found equally important contributions from fossil fuel $(46 \%)$ and biomass (54\%) aerosol sources to BC in the Himalayas; nevertheless, it was dominated by fossil fuel combustion $(66 \%)$ in the northern QTP. Correspondingly, the chemical composition of ambient aerosol in the northern QTP was also distinctly different from that in the southern QTP. Xu et al. (2014a, 2015) conducted aerosol composition studies from filter measurements of $\mathrm{PM}_{2.5}$ (particulate matter with aerodynamic diameter less than $2.5 \mu \mathrm{m}$ ) at the Qilian Shan Station observatory at the northeast edge of the QTP and found sulfate was the dominant component during summer season due to the influence of anthropogenic emissions from industrial areas in northwestern China. Similar results were also found by $\mathrm{Li}$ et al. (2013) and Zhang et al. (2014), who conducted field studies in the northeastern part of the QTP. Nitrate, oxidized from the nitrogen oxides $\left(\mathrm{NO}_{x}\right)$, was also an important component in the northern QTP which could interact with mineral dust during transport (Xu et al., 2014a). Due to the relatively lower elevation compared to the southern QTP ( $<4000$ vs. $>5000 \mathrm{~m}$ a.s.l.), the polluted air masses are easily transported to the mountain areas in the northern QTP, forced by the strong mountain-valley breeze during summer (Xu et al., 2013). Besides the significant impacts by anthropogenic emissions from the northwestern China or Indian subcontinent, air pollutants to the northeastern QTP could also come from the central Eurasian continent (Xue et al., 2013). However, most of the previous studies for characterizing the chemical properties and sources of aerosol particles in the northeastern QTP were heavily based on the filter or snow/ice samples with low time resolution ranging from days to weeks, mainly because of the absent deployment of realtime instruments at the remote region with harsh environments, challenging weather conditions and logistical difficul- ties. Studies focusing on the atmospheric aerosol chemical compositions in the northeastern QTP using the high-timeresolution real-time measurements are still relatively rare.

The Aerodyne aerosol mass spectrometer (AMS) is a unique instrument which can provide chemical composition and/or size distribution information of non-refractory submicron aerosol (NR-PM 1 ) with high time resolution and sensitivity (Jayne et al., 2000; Jimenez et al., 2003; Canagaratna et al., 2007). AMS has been widely implemented worldwide in recent decades, especially in China since 2006 due to the great concern of the atmospheric environment ( $\mathrm{Li}$ et al., 2017, and references therein). Besides the typical applications for studying air pollution in these urban/rural sites, e.g., megacities with severe haze pollution in eastern China, the AMS has also been successfully deployed at many remote sites due to its low detection limit (see details in Table 1 of Xu et al., 2018; and Table S1 of Zhang et al., 2018). In recent years, the deployments of AMS in the highland areas of the QTP have been conducted in a few field studies (Fig. S1 in the Supplement), including a high-resolution time-of-flight AMS (HR-ToF-AMS) and a soot particle AMS (SP-AMS) at Nam Co Station in the central QTP (Wang et al., 2017; Xu et al., 2018), a HR-ToF-AMS at Qomolangma Station (QOMS) in the southern QTP (Zhang et al., 2018) and a HR-ToF-AMS at Mt. Yulong in the southeastern QTP (Zheng et al., 2017). In addition to the low $\mathrm{PM}_{1}\left(\mathrm{NR}-\mathrm{PM}_{1}+\mathrm{BC}\right)$ mass loadings, the dominant contribution from organic aerosol (OA) (54\%$68 \%$ ) was found in the southern and central QTP (Zheng et al., 2017; Xu et al., 2018; Zhang et al., 2018). OA was composed by oxygenated OA (OOA) and biomass-burningrelated OA (BBOA) components in those high-altitude background sites. The OOA component was associated with the intense oxidation processes that converted the fresh OA to secondary OA, while BBOA was related to the direct emissions from the biomass burning activities in the highland areas. However, relatively few studies have been conducted in the northern QTP, except for a study reporting measurements using an Aerodyne aerosol chemical speciation monitor (ACSM) at Menyuan (Du et al., 2015).

In this study, a HR-ToF-AMS with other real-time collocated instruments was first deployed at the Waliguan (WLG) Baseline Observatory, which was one of the World Meteorological Organization's (WMO) Global Atmospheric Watch (GAW) baseline observatories, located in the northeastern QTP, to characterize the submicron aerosol chemical compositions and sources during summer season. The real-time characterizations of submicron aerosols including mass concentrations, chemical composition, size distribution, and temporal and diurnal variations were presented in details in this study. Source apportionment using positive matrix factorization (PMF) analysis on the high-resolution OA mass spectrum was conducted to investigate the sources and chemical evolution of OA during long-range transport. Finally, back trajectories of air masses were then performed to 
present the possible sources and pathway of ambient aerosols during the sampling period.

\section{Experimental methods}

\subsection{Site and measurements}

The field study was carried out during 1-31 July 2017 within the typical warm and rainy season at the Waliguan Baseline Observatory $\left(36^{\circ} 17^{\prime} \mathrm{N}, 100^{\circ} 54^{\prime} \mathrm{E}\right.$; $3816 \mathrm{~m}$ a.s.l.), which is located at the top of Mt. Waliguan at the northeast edge of the QTP in western China with an $\sim 600 \mathrm{~m}$ elevation difference from the surrounding ground (Fig. 1a and b). Mt. Waliguan is a relatively remote area and generally covered by typical highland vegetation, e.g., highland grassland and tundra, and constructed as an inland baseline station of Global Atmosphere Watch (GAW) since 1994 (http://www. wmo.int/pages/prog/arep/gaw/gaw_home_en.html, last access: 5 June 2019). The closest town, Gonghe County, is located $\sim 30 \mathrm{~km}$ to the west of Mt. Waliguan and has a population of $\sim 30000$, while Xining, the capital city of Qinghai Province, China, is the closest concentrated population center located about $90 \mathrm{~km}$ to the northeast and has a population of 2.35 million. A national road is about $9 \mathrm{~km}$ to the north of Mt. Waliguan, yet with relatively light vehicle traffic. Therefore, there are no strong anthropogenic source emissions around Mt. Waliguan. The date and time used in this study are reported in local time, i.e., Beijing Time (BJT: $\mathrm{UTC}+8 \mathrm{~h})$.

\subsection{Instrumentation}

Aerosol measurements were performed at the top floor of the main two-story building at the WLG observatory from 1 to 31 July 2017 with a suite of real-time instruments, including a HR-ToF-AMS (Aerodyne Research Inc., Billerica, MA, USA) for size-resolved chemical compositions (organics, sulfate, nitrate, ammonium and chloride) of NR-PM 1 , a photoacoustic extinctiometer (PAX, DMT Inc., Boulder, CO, USA) for particle light absorption and scattering coefficients ( $b_{\text {abs }}$ and $\left.b_{\text {scat }}\right)$ at $405 \mathrm{~nm}$ and the black carbon (BC) mass concentration through a constant mass absorption efficiency (MAE) value of $10.18 \mathrm{~m}^{2} \mathrm{~g}^{-1}$, and a cloud condensation nuclei counter (CCN-100, DMT Inc., Boulder, CO, USA) for the number concentration of cloud condensation nuclei $(\mathrm{CCN})$ that can form into cloud droplets. Simultaneously, other synchronous data were also acquired at the WLG baseline observatory during the sampling period, including the mass concentrations of $\mathrm{PM}_{2.5}$ and $\mathrm{PM}_{10}$ (particulate matter with aerodynamic diameter less than $10 \mu \mathrm{m}$ ) measured by a TEOM 1405-DF dichotomous ambient particulate monitor with a filter dynamics measurement system (Thermo Scientific, Franklin, MA, USA) and gaseous pollutants of carbon monoxide $(\mathrm{CO})$ and ozone $\left(\mathrm{O}_{3}\right)$ measured using the Thermo gas analyzers (model $48 \mathrm{i}$ and $49 \mathrm{i}$, respec- tively, Thermo Scientific, Franklin, MA, USA). The setup of instruments in this study is shown in Fig. 1d. Ambient particles were sampled through an inlet system, including a $\mathrm{PM}_{2.5}$ cyclone (model URG-2000-30EH, URG Corp., Chapel Hill, NC, USA) for removing coarse particles with size cutoffs of $2.5 \mu \mathrm{m}$, a Nafion dryer following the cyclone to dry the ambient air and eliminate the potential humidity effect on particles, and 0.5 in. $(12.7 \mathrm{~mm})$ stainless steel tubes. The inlet stepped out of the building rooftop about $1.5 \mathrm{~m}$, and the total air flow of the inlet was about $12.5 \mathrm{~L} \mathrm{~min}^{-1}$, maintained by a vacuum pump with a flow rate of $10 \mathrm{~L} \mathrm{~min}^{-1}$ for the $\mathrm{PM}_{2.5}$ size cut and the other part of the flow rate by the instruments. The room temperature was maintained at $\sim 18^{\circ} \mathrm{C}$ by two air conditioners. In addition, a Vantage Pro2 weather station (Davis Instruments Corp., Hayward, CA, USA) was set up on the building rooftop to obtain the real-time meteorology data, including ambient temperature $(T)$, relative humidity (RH), wind speed (WS), wind direction (WD), solar radiation (SR) and precipitation (Precip.).

The details of the Aerodyne HR-ToF-AMS have been described elsewhere (DeCarlo et al., 2006). Briefly, a $120 \mu \mathrm{m}$ critical orifice (replaced the typical $100 \mu \mathrm{m}$ for enhancing the transmission efficiency at a high-altitude area) and an aerodynamic lens were settled in the front inlet system to sample and focus the ambient particles into a concentrated and narrow beam. The focused particle beam exiting the lens was accelerated into the particle-sizing vacuum chamber to obtain the aerodynamic size of particles by a rotating wheel chopper. Then, particles were vaporized thermally at $\sim 600^{\circ} \mathrm{C}$ by a resistively heated surface and ionized by a $70 \mathrm{eV}$ electron impact and, finally, detected by a high-resolution mass spectrometer. The chopper generally worked at three positions alternately, i.e., open, close and chopping positions, for measuring the bulk and background signals as well as the sizeresolved spectral signals of airborne particles, respectively. Similar to most of the previous AMS field measurements, the mass spectrometer was toggled under the high-sensitivity (detection limits $\sim 10 \mathrm{ng} \mathrm{m}^{-3}$ ) $\mathrm{V}$ mode and the high-massresolution $(\sim 6000) \mathrm{W}$ mode every $5 \mathrm{~min}$ in this study. Under the V-mode operation, the instrument also switched between the mass spectrum (MS) mode and the particle P-ToF mode every $15 \mathrm{~s}$ to obtain the mass concentrations and size distributions of NR-PM $\mathrm{P}_{1}$ species, respectively, whereas the high-resolution $\mathrm{W}$ mode was used to obtain high-resolution mass spectral data. However, the data and error matrices inputted into the PMF analysis were finally generated from the V-mode data rather than the W-mode data in this study due to the low aerosol mass loading at WLG. Hence, all the data used in this study are from the $\mathrm{V}$ mode with 10 min time resolution.

\subsection{Data processing}

The HR-ToF-AMS data were processed using the standard AMS analysis software of SQUIRREL (v1.56) to 


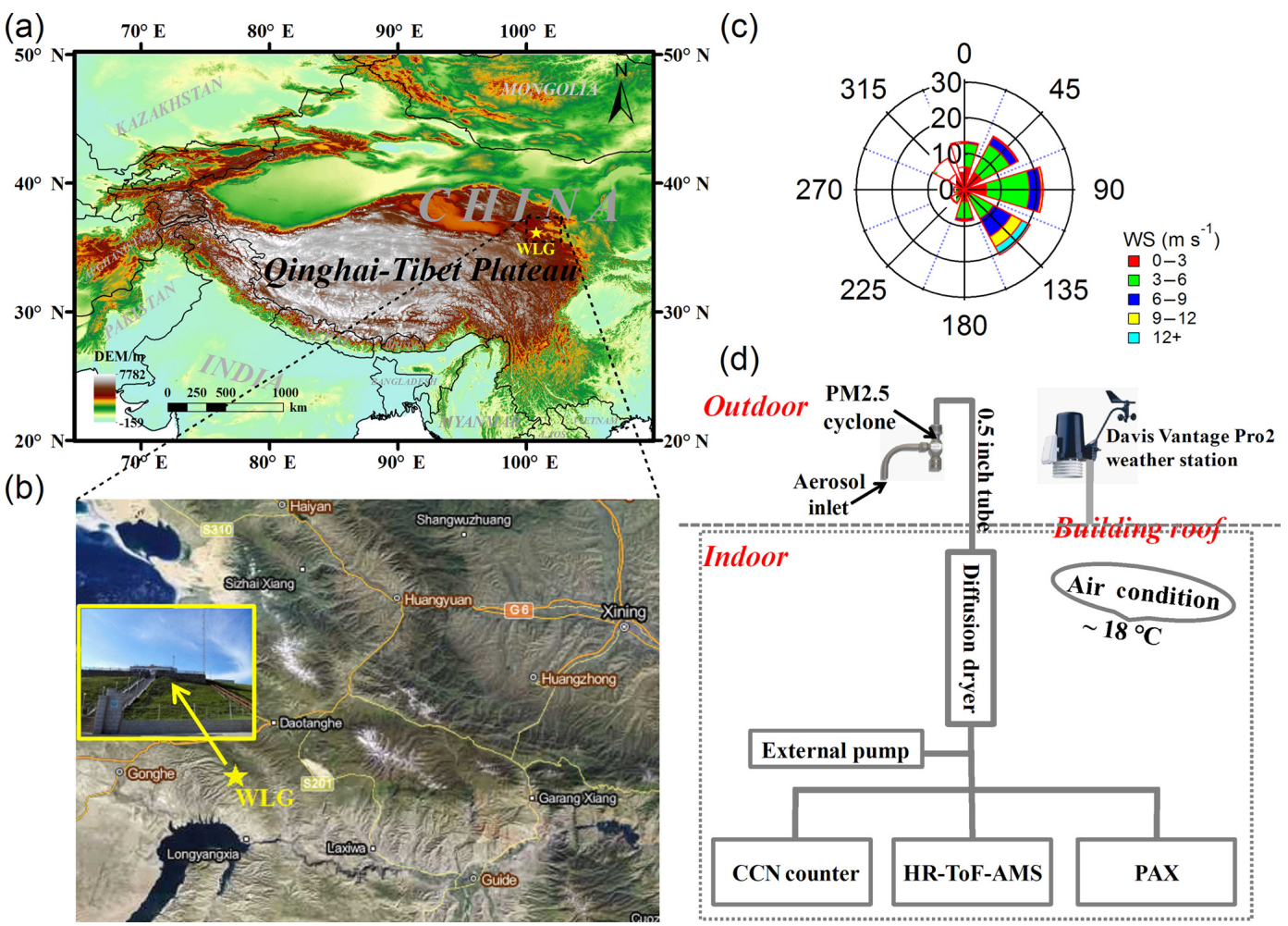

Figure 1. (a) Topography map of the Qinghai-Tibet Plateau (QTP), (b) location map of the Mt. Waliguan base (WLG; $36.283^{\circ} \mathrm{N}, 100.900^{\circ} \mathrm{E}$; $3816 \mathrm{~m}$ ), (c) the wind rose plot colored by wind speed during the field study period and (d) the setup of instruments in this study.

determine the mass concentrations and size distributions of NR-PM 1 species and the high-resolution data analysis software of PIKA (v1.15c) to analyze the ionspeciated mass spectra, components and elemental compositions (e.g., oxygen-to-carbon $(\mathrm{O} / \mathrm{C})$, hydrogen-to-carbon $(\mathrm{H} / \mathrm{C})$, nitrogen-to-carbon $(\mathrm{N} / \mathrm{C})$ and organic-mass-toorganic-carbon $(\mathrm{OM} / \mathrm{OC})$ ratios using the improved-ambient method, Canagaratna et al., 2015) of organics in this study. A collection efficiency (CE) was introduced to compensate for the incomplete transmission and detection of particles due to particle bouncing at the vaporizer and partial transmission through the aerodynamic lens. Middlebrook et al. (2012) had evaluated the dependency of CE on several ambient properties and concluded a composition-dependent CE parameterization according to the sampling line $\mathrm{RH}$, aerosol acidity and mass fraction of ammonium nitrate (ANMF). High RH, high aerosol acidity or high ANMF values would all increase the CE obviously. However, in this study, (1) aerosol particles were dried completely through a Nafion dryer in the inlet system, which made sure that the RH in the sampling line was below $40 \%$; (2) aerosol particles were just slightly acidic as indicated by the average ratio ( 0.86 ) of measured ammonium to predicted ammonium (see Sect. 3.1 and Fig. 3a for details); and (3) ANMF values were normally below 0.4 during the entire sampling period as shown in Fig. S2. Therefore, these three parameters were all expected to have negligible effects on the quantification of aerosol species from our AMS data set and thus a constant $\mathrm{CE}$ of 0.5 , which has been widely used in previous field AMS studies, was finally employed in this study.

The source apportionment of organics in this study was conducted by PMF analysis using the PMF2.exe algorithm (v4.2) (Paatero and Tapper, 1994) and PMF Evaluation Tool (PET, v2.03) (Ulbrich et al., 2009) in robust mode on the high-resolution organic mass spectrum. The PMF analysis was thoroughly evaluated following the procedures summarized in Table 1 of Zhang et al. (2011), including modifying the error matrix, down-weighting or removing the low signalto-noise $(S / N)$ ions. For example, the signals of $\mathrm{H}_{2} \mathrm{O}^{+}$and $\mathrm{CO}^{+}$for organics were scaled to that of $\mathrm{CO}_{2}^{+}$as $\mathrm{CO}^{+}=\mathrm{CO}_{2}^{+}$ and $\mathrm{H}_{2} \mathrm{O}^{+}=0.225 \times \mathrm{CO}_{2}^{+}$, while signals of $\mathrm{HO}^{+}$and $\mathrm{O}^{+}$ were set as $\mathrm{HO}^{+}=0.25 \times \mathrm{H}_{2} \mathrm{O}^{+}$and $\mathrm{O}^{+}=0.04 \times \mathrm{H}_{2} \mathrm{O}^{+}$according to Aiken et al. (2008). Then the above four ions were further down-weighted by increasing their errors by a factor of 2 in PMF analysis. Isotopic ions were generally excluded because their signals are not directly measured. The "bad" ions with $S / N<0.2$ were removed from the data and error matrices, while the "weak" ions with $0.2<S / N<2$ were down-weighted by increasing their errors. In addition, some runs with huge residual spikes, e.g., data with much too low mass loadings related to the heavy rain on 27 July 2017, were also removed from the data and error matrices. A summary 
of the key diagnostic plots of PMF results for this study is presented in Fig. S3. Overall, the PMF solutions were investigated from one to six factors with the rotational parameter ( $f$ Peak) varying from -1 to 1 with a step of 0.1 . Finally, a four-factor solution with $f$ Peak $=0$ was chosen in this study by examining the model residuals, scaled residuals, and $Q / Q_{\exp }$ contributions for each $m / z$ and time, as well as comparing the mass spectra of individual factors with reference spectra and the time series of individual factors with external tracers. The mass spectra, time series and diurnal variations of PMF results from three-factor and five-factor solutions were also shown in Figs. S4 and S5 for comparison, respectively. The three-factor solution did not separate the two biomass burning factors, whereas the five-factor solution showed a splitting factor.

\section{Results and discussion}

\subsection{Size-resolved chemical characteristics of $\mathbf{P M}_{1}$}

An overview of temporal variations of mass concentrations and fractions of $\mathrm{PM}_{1}$ chemical species (organics, sulfate, nitrate, ammonium, chloride and $\mathrm{BC}$ ) as well as meteorological conditions ( $T, \mathrm{RH}, \mathrm{WS}, \mathrm{WD}$ and Precip.), mass concentrations of relevant particulate matters $\left(\mathrm{PM}_{2.5}\right.$ and $\left.\mathrm{PM}_{10}\right)$ and gaseous pollutants $\left(\mathrm{O}_{3}\right.$ and $\left.\mathrm{CO}\right)$, and mass fractions of organic components are shown in Fig. 2, respectively. The missing data are due to hardware or software malfunction, maintenance of the instrument, or removal of large spikes and the unique burning event (a local Tibetan festival event occurred during 5-6 July 2017 with extremely high aerosol mass loadings) in data processing. Air temperature $(T)$ ranged from 8.5 to $14.5^{\circ} \mathrm{C}$ for the averaged diurnal variation during the study, with an average $( \pm 1 \sigma)$ of $11.0 \pm 2.0^{\circ} \mathrm{C}$, while relative humidity ranged from $55.9 \%$ to $73.5 \%$ with an average of $66.6 \pm 5.7 \%$ (Fig. S6). The wind directions at WLG were predominantly eastern, southeastern and northeastern during this study, with an average wind speed of $4.4 \pm 2.8 \mathrm{~m} \mathrm{~s}^{-1}$ (Figs. $1 \mathrm{c}$ and $2 \mathrm{~b}$ ). In addition, WD generally changed from eastern to southeastern during nighttime with WS higher than $4 \mathrm{~m} \mathrm{~s}^{-1}$ but from northwestern to northeastern during daytime with relatively lower WS (Fig. S6). Two moderate rain events occurred during 2-9 and 22-28 July 2017, with a daily mean precipitation of 2.6 and $7.4 \mathrm{~mm} \mathrm{~d}^{-1}$, respectively (Fig. 2a).

The total $\mathrm{PM}_{1}$ mass varied dynamically throughout this study with mass concentration ranging from 0.3 to $28.1 \mu \mathrm{g} \mathrm{m}^{-3}$. This dynamic variation pattern could also be found for the mass concentrations of $\mathrm{PM}_{2.5}, \mathrm{PM}_{10}$ and $\mathrm{CO}$, with their correlation coefficients $\left(R^{2}\right)$ versus $\mathrm{PM}_{1}$ varying reasonably from 0.39 to 0.63 (Figs. 2 and S7). In addition, $\mathrm{PM}_{1}$ accounted for $66 \%$ of $\mathrm{PM}_{2.5}$ mass in this study (Fig. S7), reflecting the essential contribution of submicron aerosols at WLG. Overall, the average mass concen- tration of total $\mathrm{PM}_{1}( \pm 1 \sigma)$ at WLG for the entire study was $9.1( \pm 5.3) \mu \mathrm{g} \mathrm{m}^{-3}$, which was much higher than those at other high-elevation sites in the QTP measured with the Aerodyne AMS, such as $2.0 \mu \mathrm{g} \mathrm{m}^{-3}$ between 31 May and 1 July 2015 at Nam Co Station (4730 ma.s.l.) in the central QTP (Xu et al., 2018), $4.4 \mu \mathrm{g} \mathrm{m}^{-3}$ between 12 April and 12 May 2016 at QOMS (4276 m a.s.l.) at the south edge of the QTP (Zhang et al., 2018), and $5.7 \mu \mathrm{g} \mathrm{m}^{-3}$ between 22 March and 14 April 2015 at Mt. Yulong (3410 m a.s.l.) at the southeastern QTP (Zheng et al., 2017), whereas this value was comparable with that $\left(11.4 \mu \mathrm{g} \mathrm{m}^{-3}\right)$ measured with an Aerodyne ACSM between 5 September and 15 October 2013 at Menyuan (3295 ma.s.l.) at the northeastern QTP (Du et al., 2015). The higher $P_{1}$ mass concentration at WLG in the northeastern QTP compared to those at other sites in the central or southern QTP was likely due to the relatively shorter distance from the industrial areas (e.g., Xining city) in northwestern China and strong mountain-valley breeze during summer. This conclusion could be supported by the comparisons of air mass back trajectories between WLG in this study (see Sect. 3.4 for details) and those at Nam Co Station in Xu et al. (2018) and QOMS in Zhang et al. (2018). Sulfate and organics were the two dominant $\mathrm{PM}_{1}$ species at WLG, accounting for $38.1 \%$ and $34.5 \%$ on average, respectively, followed by ammonium (15.2\%), nitrate $(8.1 \%)$, BC (3.0\%) and chloride (1.1\%). This chemical composition of $\mathrm{PM}_{1}$ at WLG was quite different from those at Nam Co Station, QOMS and Mt. Yulong sites in the central or southern QTP (Zheng et al., 2017; Xu et al., 2018; Zhang et al., 2018), where organics were the dominant species, accounting for $54 \%-68 \%$ of total $\mathrm{PM}_{1}$ mass due to the significant contribution of biomass burning emissions, whereas sulfate only contributed $9 \%-15 \%$ of total $\mathrm{PM}_{1}$. The consistent high contribution of sulfate was also observed at Menyuan $(28 \%)$ in the northeastern QTP and other rural and remote sites (19\%$64 \%$ ) in East Asia, which were far away from urban areas, as that summarized in Fig. 1 in Du et al. (2015). Moreover, as displayed in Fig. 3b, the mass contribution of sulfate increased significantly with the increase in total $\mathrm{PM}_{1}$ mass (lower than $15 \%$ for $\mathrm{PM}_{1}$ mass equal to $1.0 \mu \mathrm{g} \mathrm{m}^{-3}$ and increased to more than $45 \%$ for $\mathrm{PM}_{1}$ mass of $20.0 \mu \mathrm{g} \mathrm{m}^{-3}$ ), suggesting the important contribution of sulfate to submicron aerosols at WLG.

Bulk acidity of $\mathrm{PM}_{1}$ at WLG was also evaluated according to the method in Zhang et al. (2007). The predicted ammonium was calculated based on the mass concentrations of sulfate, nitrate, and chloride and assumed full neutralization of these anions by ammonium. The $\mathrm{PM}_{1}$ appeared to be slightly acidic throughout this study, as indicated by the scatter plot between the measured and predicted ammonium in Fig. 3a (Slope $=0.86, R^{2}=0.98$ ). The acidic feature of aerosol particles at WLG was consistent with those results at Menyuan (Du et al., 2015) and Qilian Shan Mountain (Xu et al., 2015), with both located in the northeastern QTP, but different from those at Nam Co Station (Xu et al., 2018) 


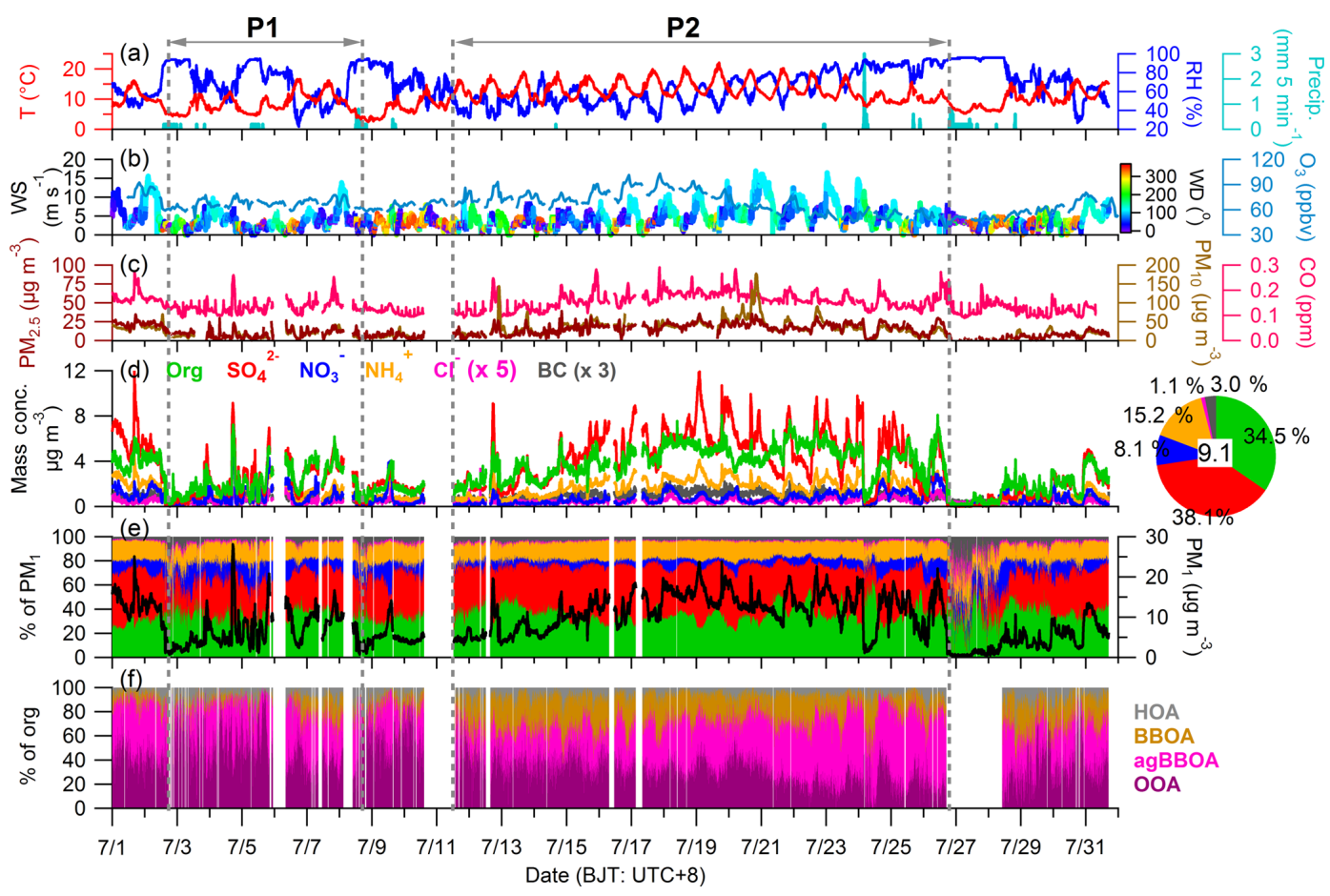

Figure 2. Time series of (a) ambient temperature ( $T$ ), relative humidity (RH) and precipitation (Precip.); (b) wind speed (WS) colored by wind direction (WD) and $\mathrm{O}_{3}$; (c) mass concentrations of $\mathrm{PM}_{2.5}, \mathrm{PM}_{10}$ and $\mathrm{CO}$; (d) mass concentrations of $\mathrm{PM}_{1}$ species; (e) mass contributions of $\mathrm{PM}_{1}$ species as well as the total $\mathrm{PM}_{1}$ mass concentrations; and (f) mass contributions of four organic components. The pie chart shows the average chemical composition of $\mathrm{PM}_{1}$ for the entire study period, with the average $\mathrm{PM}_{1}$ mass concentration (unit of $\mu \mathrm{g} \mathrm{m}^{-3}$ ) marked in the center.

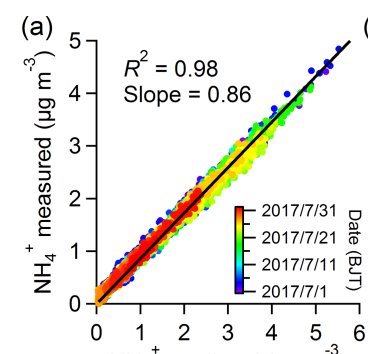

(b) $\mathrm{NH}_{4}^{+}$predicted $\left(\mu \mathrm{g} \mathrm{m}^{-3}\right)$ (d)
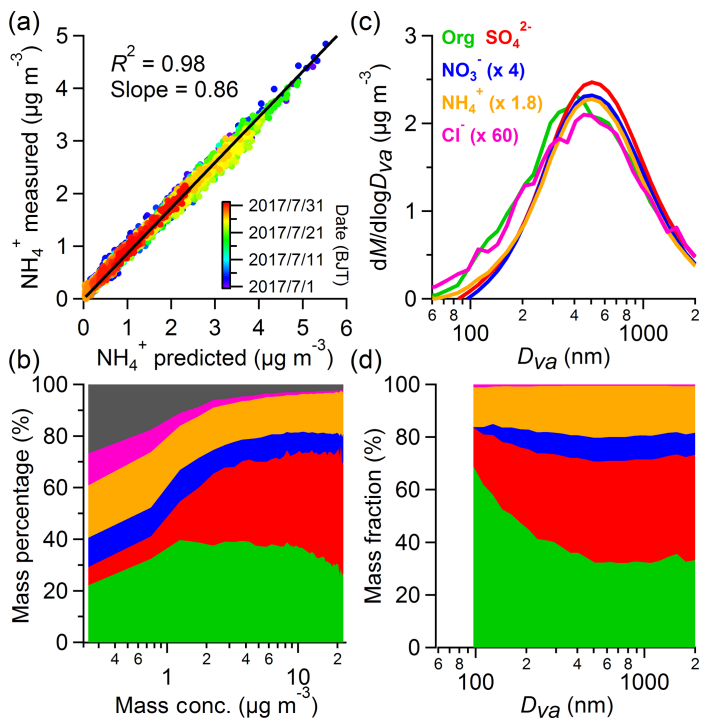

Figure 3. (a) Scatterplot and linear regression (black solid line) of measured $\mathrm{NH}_{4}^{+}$versus predicted $\mathrm{NH}_{4}^{+}$based on the mass concentrations of $\mathrm{SO}_{4}^{2-}, \mathrm{NO}_{3}^{-}$and $\mathrm{Cl}^{-}$; (b) the mass contributions of $\mathrm{PM}_{1}$ chemical species as a function of total $\mathrm{PM}_{1}$ mass concentration; and the average size distributions of (c) mass concentrations and (d) mass contributions of NR-PM 1 species in this study. and QOMS (Zhang et al., 2018) in the central or southern QTP, where bulk aerosol particles were generally neutralized or excesses of ammonium. The enriched sulfate in the northeastern QTP might be related to the enhanced coal consumption in the northwest of China and aqueous processing by cloud at the mountains. This conclusion could be further demonstrated by the emission distribution of sulfur dioxide $\left(\mathrm{SO}_{2}\right)$ in China observed by the Ozone Monitoring Instrument (OMI) satellite data in previous studies (Lu et al., 2011; van der A et al., 2017), where $\mathrm{SO}_{2}$ showed considerable concentrations in the northwest of China, especially in urban areas like Xining and Lanzhou cities, whereas extremely low concentrations occurred in the southern QTP.

The average chemically resolved size distributions of mass concentrations of NR-PM $\mathrm{PM}_{1}$ species are shown in Fig. 3c. Overall, all chemical species peaked at the accumulation mode with different peaking sizes, e.g., $\sim 400 \mathrm{~nm}$ in aerodynamic diameter $\left(D_{\mathrm{va}}\right)$ for organics, $\sim 450 \mathrm{~nm}$ for chloride and $\sim 500 \mathrm{~nm}$ for the remaining three secondary inorganic species (sulfate, nitrate and ammonium), indicating the wellmixed and highly aged aerosol particles at WLG during the sampling period. Moreover, organics presented a relatively wider distribution than the three secondary inorganic species in the small sizes $(<300 \mathrm{~nm})$. This could also be clearly revealed by the variations of mass contribution of chemical 
species as a function of particle sizes in Fig. 3d. The contribution of organics decreased noticeably with the increasing sizes, whereas those of three inorganic species, especially sulfate, increased correspondingly. Specifically, organics could contribute more than half of the ultrafine NR-PM $\left(D_{\mathrm{va}}<100 \mathrm{~nm}\right)$ that may be associated with the existing relatively fresh sources of organic particles, while the three inorganic species dominated (more than $60 \%$ ) at the accumulation mode due to their highly aged properties.

\subsection{Bulk characteristics and elemental composition of OA}

The average high-resolution mass spectrum (HRMS) and elemental compositions of $\mathrm{OA}$ during the study are shown in Fig. 4a. Note that the elemental ratios of $\mathrm{O} / \mathrm{C}, \mathrm{H} / \mathrm{C}, \mathrm{N} / \mathrm{C}$ and $\mathrm{OM} / \mathrm{OC}$ in this study were all determined using the improved-ambient method (Canagaratna et al., 2015), which increased $\mathrm{O} / \mathrm{C}$ by $29 \%, \mathrm{H} / \mathrm{C}$ by $14 \%$ and $\mathrm{OM} / \mathrm{OC}$ by $15 \%$ on average, respectively, compared to those determined from the Aiken ambient method (Aiken et al., 2008) (Fig. S8). The average HRMS of OA was quite similar to those at other locations, e.g., Menyuan (Du et al., 2015), Nam Co Station (Xu et al., 2018) and QOMS (Zhang et al., 2018) in the QTP, with a significantly high contribution at $\mathrm{m} / \mathrm{z} 44$ (17.9\%; composed totally by $\mathrm{CO}_{2}^{+}$in this study and similarly hereinafter). On average, $\mathrm{C}_{x} \mathrm{H}_{y} \mathrm{O}_{1}^{+}$dominated the total OA $(44.0 \%)$ followed by $\mathrm{C}_{x} \mathrm{H}_{y}^{+}(27.9 \%), \mathrm{C}_{x} \mathrm{H}_{y} \mathrm{O}_{2}^{+}(21.7 \%), \mathrm{H}_{y} \mathrm{O}_{1}^{+}(5.1 \%)$, $\mathrm{C}_{x} \mathrm{H}_{y} \mathrm{~N}_{\mathrm{p}}^{+}(1.0 \%)$ and $\mathrm{C}_{x} \mathrm{H}_{y} \mathrm{O}_{\mathrm{z}} \mathrm{N}_{\mathrm{p}}^{+}(0.2 \%)$, as shown in the pie chart in Fig. 4a. The total contribution of the two major oxygenated ion fragments $\left(\mathrm{C}_{x} \mathrm{H}_{y} \mathrm{O}_{\mathrm{z}}^{+}\right)$was $65.7 \%$ at WLG, which was comparable to those values at Nam Co Station during 31 May-1 July 2015 (57.9\%; Xu et al., 2018) and QOMS during 12 April-12 May 2016 (66.2\%; Zhang et al., 2018), whereas it was much higher than that $(38.0 \%)$ measured during 11 July-7 August 2012 at Lanzhou (Xu et al., 2014b). In addition, the average $\mathrm{O} / \mathrm{C}$ ratio of 0.99 in this study was also comparable with those at Nam Co Station ( 0.88 ; determined by the improved-ambient method and similarly hereinafter; Xu et al., 2018) and QOMS (1.07; Zhang et al., 2018) but quite higher than those observed at various urban and rural sites in China during summertime, e.g., 0.53 and 0.56 in Beijing, 0.40 in Shanghai, 0.41 in Shenzhen and 0.36 in Jiaxing (Hu et al., 2017). As either the contributions of $\mathrm{CO}_{2}^{+}$and $\mathrm{C}_{x} \mathrm{H}_{y} \mathrm{O}_{\mathrm{z}}^{+}$or element ratio of $\mathrm{O} / \mathrm{C}$ are generally considered good indicators for the aging degree of $\mathrm{OA}$, the relatively higher values at WLG as well as at other sites in the QTP together indicated that OA in the QTP was highly oxidized due to the absence of local emissions and long-range transport.

Diurnal cycles of $\mathrm{O} / \mathrm{C}$ and $\mathrm{OM} / \mathrm{OC}$ ratios in this study varied shallowly within $0.96-1.05$ and $2.40-2.52$, respectively, suggesting an overall OA source from regional transport at WLG (Fig. 4b). The relatively higher $\mathrm{O} / \mathrm{C}$ and $\mathrm{OM} / \mathrm{OC}$ ratios during the afternoon potentially related to
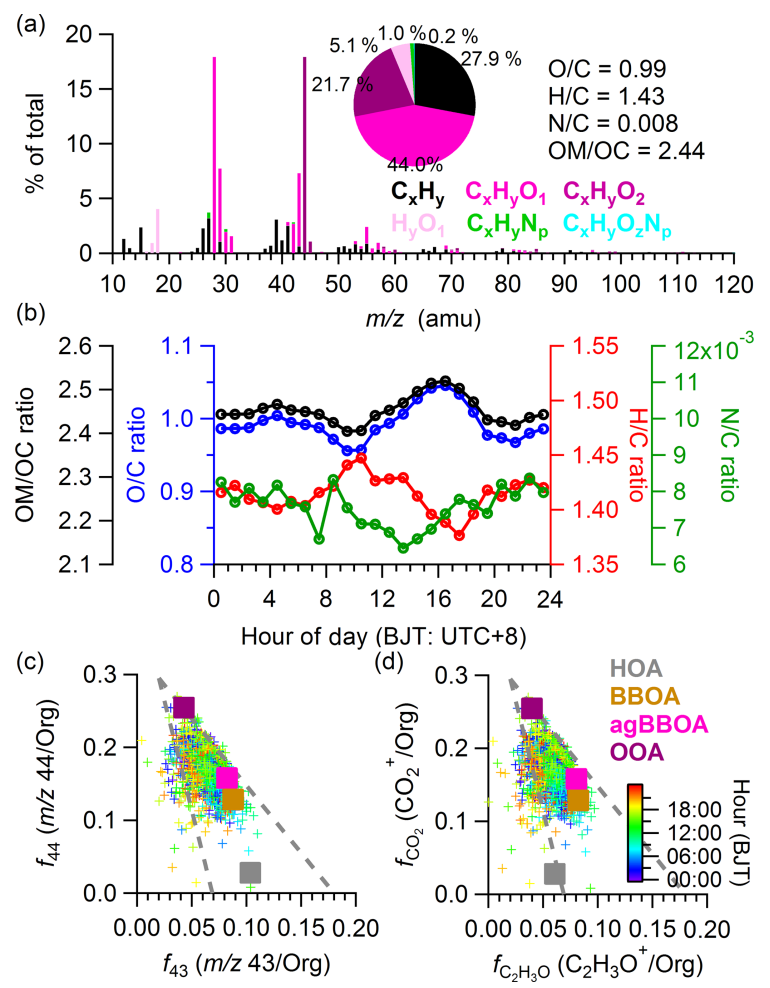

Figure 4. (a) The average high-resolution mass spectrum of organics colored with six ion categories (pie chart shows the average contributions of the six ion categories); (b) diurnal variations of element ratios $(\mathrm{O} / \mathrm{C}, \mathrm{H} / \mathrm{C}, \mathrm{N} / \mathrm{C}$ and $\mathrm{OM} / \mathrm{OC})$; and scatterplots of (c) $f 44$ vs. $f 43$ and (d) $f \mathrm{CO}_{2}^{+}$vs. $f \mathrm{C}_{2} \mathrm{H}_{3} \mathrm{O}^{+}$colored by time of the day, where the corresponding values of four organic components are also shown.

the photochemical oxidation processes in the daytime, while lower values in the late morning mainly associated with the transport of relatively fresh OA from nearby areas to the WLG site, which could be further revealed by the corresponding higher $\mathrm{H} / \mathrm{C}$ and $\mathrm{N} / \mathrm{C}$ ratios in the late morning as well as the diurnal variations of the two primary OA components (see Sect. 3.3 for details). Correspondingly, the $\mathrm{H} / \mathrm{C}$ ratio presented an opposite diurnal pattern compared to $\mathrm{O} / \mathrm{C}$. The elemental ratios in the Van Krevelen diagram $(\mathrm{H} / \mathrm{C}$ versus $\mathrm{O} / \mathrm{C}$ ), which had been used widely to probe the oxidation reaction mechanisms for bulk $\mathrm{OA}$, were calculated following a slope of -0.64 in this study (Fig. S8), which suggested that the OA oxidation mechanism at WLG was a combination of carboxylic acid groups with fragmentation and alco$\mathrm{hol} /$ peroxide functional groups without fragmentation (Heald et al., 2010).

\subsection{Source apportionment of $\mathrm{OA}$}

PMF analysis on the OA HRMS identified four distinct components, i.e., a traffic-related hydrocarbon-like OA (HOA), a relatively fresh biomass burning OA (BBOA), an aged 
biomass burning OA (agBBOA) and a more-oxidized oxygenated OA (OOA) in this study. Each of the OA components had unique characteristics on mass spectral profile, average element ratios, diurnal pattern, and temporary variation as well as tight correlations with corresponding tracers. The details on the source apportionment results of OA are given as follows.

Figure 5 shows the average HRMS and temporal variation of each OA component, respectively. A traffic-related hydrocarbon-like $\mathrm{OA}$, with the lowest $\mathrm{O} / \mathrm{C}$ ratio $(0.33)$ and the highest $\mathrm{H} / \mathrm{C}$ ratio (1.83) among the four factors, was identified in this study. Similar to several HOA mass spectra reported in previous studies (Zhang et al., 2005; $\mathrm{Ng}$ et al., 2011), HRMS of HOA in this study was also dominated by hydrocarbon ion series of $\mathrm{C}_{n} \mathrm{H}_{2 n \pm 1}^{+}$, especially $\mathrm{C}_{3} \mathrm{H}_{5}^{+}$ $(m / z=41), \mathrm{C}_{3} \mathrm{H}_{7}^{+}(m / z=43), \mathrm{C}_{4} \mathrm{H}_{7}^{+}(m / z=55), \mathrm{C}_{4} \mathrm{H}_{9}^{+}$ $(m / z=57), \mathrm{C}_{5} \mathrm{H}_{9}^{+}(m / z=69)$ and $\mathrm{C}_{5} \mathrm{H}_{11}^{+}(m / z=71)$, as shown in Fig. 5a. Consequently, the dominant contribution of ion fragments was $\mathrm{C}_{x} \mathrm{H}_{y}^{+}(62.8 \%)$ followed by $\mathrm{C}_{x} \mathrm{H}_{y} \mathrm{O}_{1}^{+}$ $(29.3 \%)$ and $\mathrm{C}_{x} \mathrm{H}_{y} \mathrm{O}_{2}^{+}(6.1 \%)$ (Fig. S9), suggesting the primary feature of HOA compared to other OA components. The two dominant ions, $m / z 57$ (mainly $\mathrm{C}_{4} \mathrm{H}_{9}^{+}$and $\mathrm{C}_{3} \mathrm{H}_{5} \mathrm{O}^{+}$) and $m / z 55$ (mainly $\mathrm{C}_{4} \mathrm{H}_{7}^{+}$and $\mathrm{C}_{3} \mathrm{H}_{3} \mathrm{O}^{+}$), which are generally associated with primary organics from combustion sources, are commonly considered tracers for HOA in previous studies (Zhang et al., 2005). In our study, HOA contributed $71 \%$ and $27 \%$ to $\mathrm{C}_{4} \mathrm{H}_{7}^{+}$and $\mathrm{C}_{3} \mathrm{H}_{3} \mathrm{O}^{+}$, respectively, at $m / z 55$ and $89 \%$ and $29 \%$ to $\mathrm{C}_{4} \mathrm{H}_{9}^{+}$and $\mathrm{C}_{3} \mathrm{H}_{5} \mathrm{O}^{+}$at $m / z 57$. The time series of HOA correlated closely with those of $\mathrm{C}_{4} \mathrm{H}_{9}^{+}\left(R^{2}=0.68\right.$, Fig. 5e $)$ and other alkyl fragments, like $\mathrm{C}_{3} \mathrm{H}_{7}^{+}, \mathrm{C}_{4} \mathrm{H}_{7}^{+}$and $\mathrm{C}_{5} \mathrm{H}_{9}^{+}\left(R^{2}=0.52-0.65\right.$, Fig. $\left.\mathrm{S} 10\right)$. Besides, the high-resolution mass spectrum of HOA was highly similar to those from other locations around the world (Aiken et al., 2009; Elser et al., 2016; Hu et al., 2016), with correlation coefficients $\left(R^{2}\right)$ varying from 0.62 to 0.94 (Fig. S11). Diurnal variation of HOA (Fig. 6c and d) in this study presented two slight peaks in the late morning (around 10:00 BJT) and evening (around 20:00 BJT). Although there was no traffic rush hour in the high-elevation site, the increasing vehicles on the national road combined with the valley breeze together lead to the slightly higher HOA concentrations in the late morning, and then HOA decreased continuously with the increasing planetary boundary layer (PBL) height in the afternoon and elevated again to a stable high level during nighttime due to the low PBL height and mountain breeze. Note that the $\mathrm{O} / \mathrm{C}$ ratio of HOA in this study was obviously higher than those (generally lower than 0.2 ) observed in either urban sites or laboratory studies, which have intense local traffic emissions (He et al., 2010; Sun et al., 2011; Xu et al., 2016). The reason is mainly due to the regional transport of traffic emissions to WLG. As mentioned in Sect. 2.1, one national road is about $9 \mathrm{~km}$ to the north of Mt. Waliguan yet with relatively light vehicle traffic. Hence, the traffic-related aerosols from either the national road or nearby towns and cities would undergo certain oxidation processes during transportation to the WLG site.

Two biomass-burning-related OA factors, a relatively fresh biomass burning OA and an aged biomass burning OA, with distinctly different oxidation degrees, were also found in this study. Although the $m / z 44$ signals were still the highest peaks for the two factors, the $m / z 60$ signals, which were generally regarded as well-known tracers for biomass burning emissions (Alfarra et al., 2007), were also obvious in both HRMSs. The fractions of the signals at $m / z 60\left(f_{60}\right)$ in their HRMS were $0.51 \%$ and $0.46 \%$, respectively, which were significantly higher than the typical value of $0.3 \%$ that has been widely used as a background level in air masses not impacted by active open biomass burning in previous studies (Cubison et al., 2011; Zhou et al., 2017), demonstrating the presence of biomass-burning-related OA factors at the WLG site. As shown in Fig. 5, the time series of agBBOA correlated tightly with $\mathrm{C}_{2} \mathrm{H}_{4} \mathrm{O}_{2}^{+}\left(R^{2}=0.79\right)$ and sulfate $\left(R^{2}=0.47\right)$, while BBOA correlated slightly with $\mathrm{C}_{2} \mathrm{H}_{4} \mathrm{O}_{2}^{+}\left(R^{2}=0.47\right)$ and potassium $\left(R^{2}=0.30\right)$, respectively. The time series of agBBOA also correlated well with $\mathrm{C}_{x} \mathrm{H}_{y} \mathrm{O}_{1}^{+}$and $\mathrm{C}_{x} \mathrm{H}_{y} \mathrm{O}_{2}^{+}$ions, while BBOA correlated well with $\mathrm{C}_{x} \mathrm{H}_{y}^{+}$and $\mathrm{C}_{x} \mathrm{H}_{y} \mathrm{O}_{1}^{+}$(Fig. S10). In addition, the mass spectra of the two biomass-burning-related OA factors resembled well that of BBOA at QOMS ( $R^{2}$ of 0.886 and 0.954, respectively; Fig. S11; Zhang et al., 2018), whereas it correlated moderately $\left(R^{2}=0.39-0.59\right)$ with other standard BBOA mass spectra at other sites around the world (Aiken et al., 2009; Mohr et al., 2012). The agBBOA mass spectrum in this study correlated tightly $\left(R^{2}=0.914\right)$ with the lessoxidized oxygenated OA (LOOOA) identified at Nam Co Station (Fig. S11; Xu et al., 2018). All these comparisons and correlation analyses further verified the reasonable source apportionment of OA in this study, namely there were two biomass-burning-related OAs at WLG, as a result of the different oxidation degrees of biomass burning emissions transported from surrounding areas to the WLG site (see Sect. 3.4 for details). Similar OA source apportionment of two BBOA components with different oxidation degrees has also been resolved in previous studies, e.g., an additional oxygenated biomass-burning-influenced organic aerosol $\left(\mathrm{OOA}_{2}-\mathrm{BBOA}\right.$ or OOA-BB) in the Paris metropolitan area (Crippa et al., 2013), urban Nanjing (Zhang et al., 2015) and Mt. Yulong (Zheng et al., 2017), respectively, besides the relatively fresh BBOA component. The $\mathrm{O} / \mathrm{C}$ and $\mathrm{OM} / \mathrm{OC}$ ratios for the relatively fresh biomass burning OA were 0.69 and 2.06, respectively, with much higher values of 1.02 and 2.49 for the aged biomass burning OA. Correspondingly, the $\mathrm{C}_{x} \mathrm{H}_{y} \mathrm{O}_{z}^{+}$fragment also showed higher contribution for agBBOA than that for BBOA (67.8\% vs. 56.6\%; Fig. S9). Moreover, the O/C ratio of BBOA in this study was also obviously higher than those in other urban or rural sites in China, which had direct or local biomass burning sources, e.g., 0.24 in Lanzhou (Xu et al., 2016), 0.36 in Beijing (Sun et al., 2016) and 0.26 in Kaiping (Huang et al., 2011). The diurnal patterns of the 

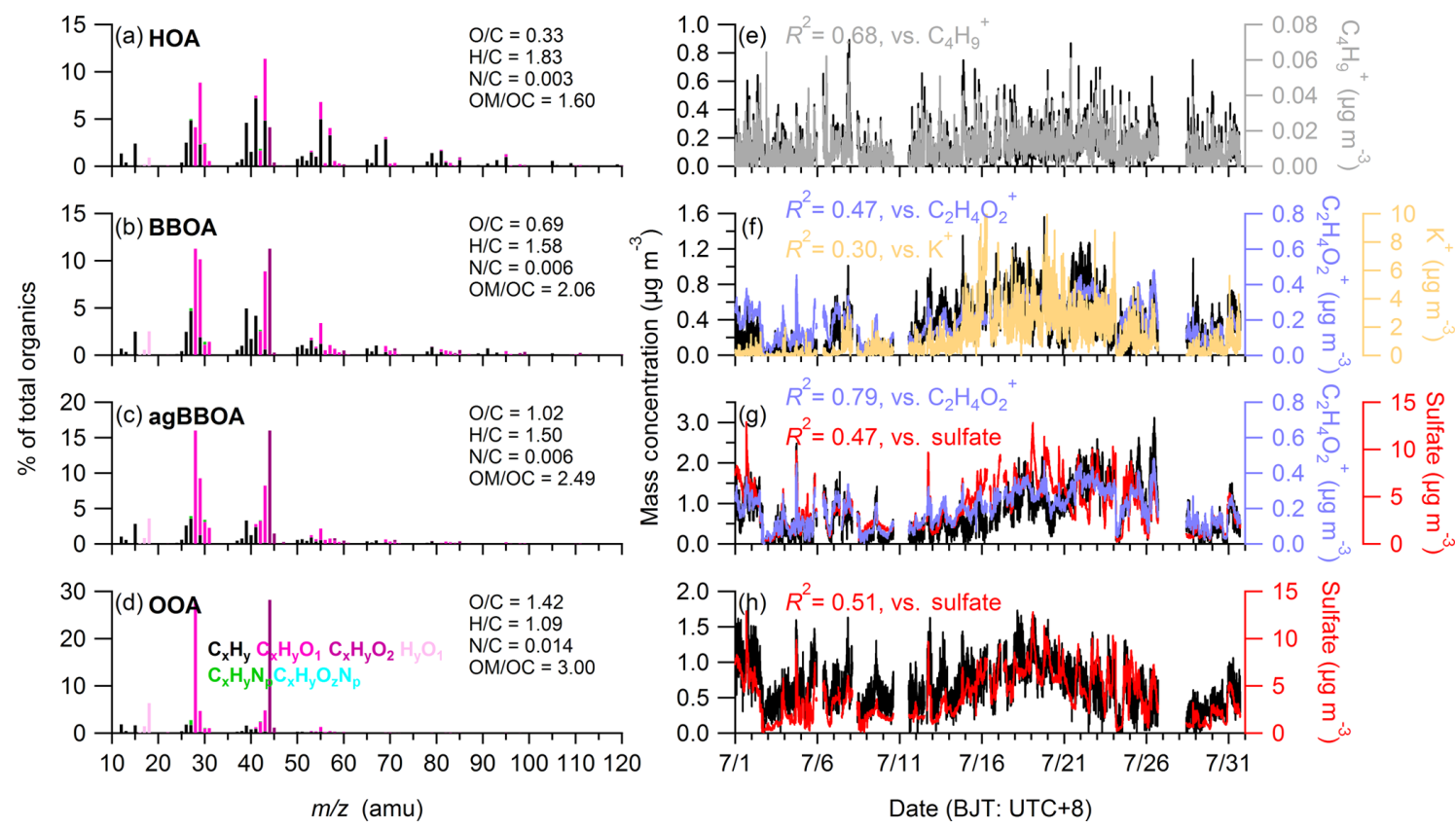

Figure 5. PMF results of (a, b, c, d) high-resolution mass spectra colored by six ion categories for the four OA factors at $m / z<120 ;(\mathbf{e}, \mathbf{f}, \mathbf{g}$, h) temporal variations of the four OA factors and corresponding comparison with tracer species.

(a)
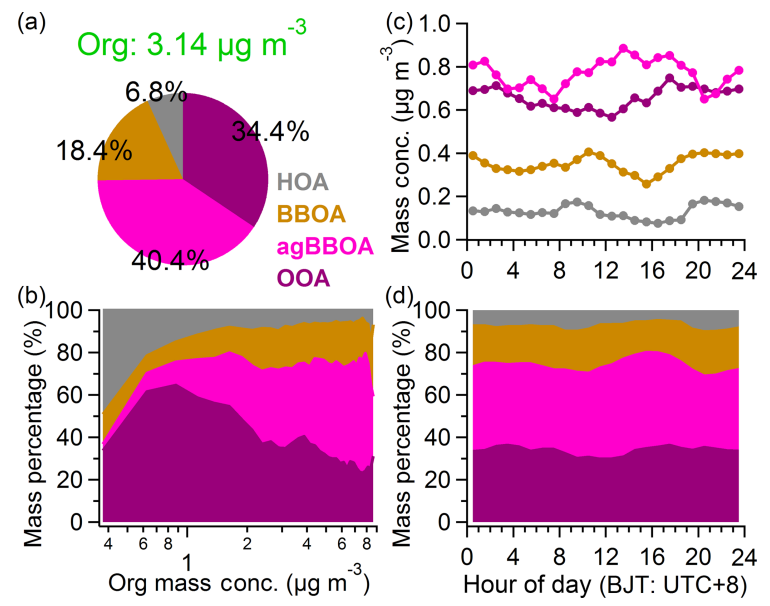

Figure 6. The average mass contributions of four organic components to total organics (a) during the entire study period and (b) as a function of total organics mass concentrations, as well as the diurnal variations of (c) mass concentrations and (d) mass contributions of four organic components in this study.

two biomass-burning-related OAs presented nearly opposite trends in this study (Fig. $6 \mathrm{c}$ and d), with high values during nighttime and decreased trend in the afternoon for BBOA, whereas they increased obviously during daytime for agBBOA, mainly associated with the possible aging evolution from $\mathrm{BBOA}$ to agBBOA via photochemical oxidation during daytime.
Another OA component, characterized by the highest peak at $m / z 44$ (contributed $\sim 28 \%$ of total signal), the highest average $\mathrm{O} / \mathrm{C}(1.42)$ and $\mathrm{OM} / \mathrm{OC}(3.00)$ and the highest contribution of $\mathrm{C}_{x} \mathrm{H}_{y} \mathrm{O}_{z}^{+}$fragment $\left(44.5 \%\right.$ of $\mathrm{C}_{x} \mathrm{H}_{y} \mathrm{O}_{1}^{+}$and $30.6 \%$ of $\mathrm{C}_{x} \mathrm{H}_{y} \mathrm{O}_{2}^{+}$; Fig. S9) among the four factors, was identified as an oxygenated OA (OOA) in this study. The OOA HRMS in this study was quite similar to those of moreoxidized oxygenated OA (MO-OOA) or low-volatility oxygenated OA (LV-OOA) factors identified frequently in previous AMS studies (Fig. S11), e.g., Nam Co Station $\left(R^{2}=\right.$ 0.995; Xu et al., 2018) and QOMS $\left(R^{2}=0.997\right.$; Zhang et al., 2018), suggesting that this factor mainly represented a typical regional oxygenated OA. The time series of OOA in this study correlated closely with the main secondary inorganic species, sulfate $\left(R^{2}=0.51\right)$, indicating their commonly regional and aged properties. In addition, the time series of OOA also correlated well with $\mathrm{C}_{x} \mathrm{H}_{y} \mathrm{O}_{2}^{+}$ions, especially with $\mathrm{CO}_{2}^{+}\left(R^{2}=0.62\right)$ as shown in Fig. S10. Although OOA showed relatively stable contributions throughout the whole day, the OOA mass concentrations also presented distinct diurnal variation at the WLG site, namely relatively low values in the late morning, continuously increasing trend during the afternoon and moderate values at nighttime (Fig. $6 \mathrm{c}$ and d), which tightly associated with the photochemical activities in the daytime, aqueous processing of $\mathrm{OA}$ at nighttime and the diurnal variation of PBL height.

Overall, the average mass concentration of organics was $3.14 \mu \mathrm{g} \mathrm{m}^{-3}$ for the entire study and composed by $34.4 \%$ of OOA, $40.4 \%$ of agBBOA, $18.4 \%$ of BBOA and $6.8 \%$ of HOA on average (Fig. 6a). The biomass-burning-related OA 


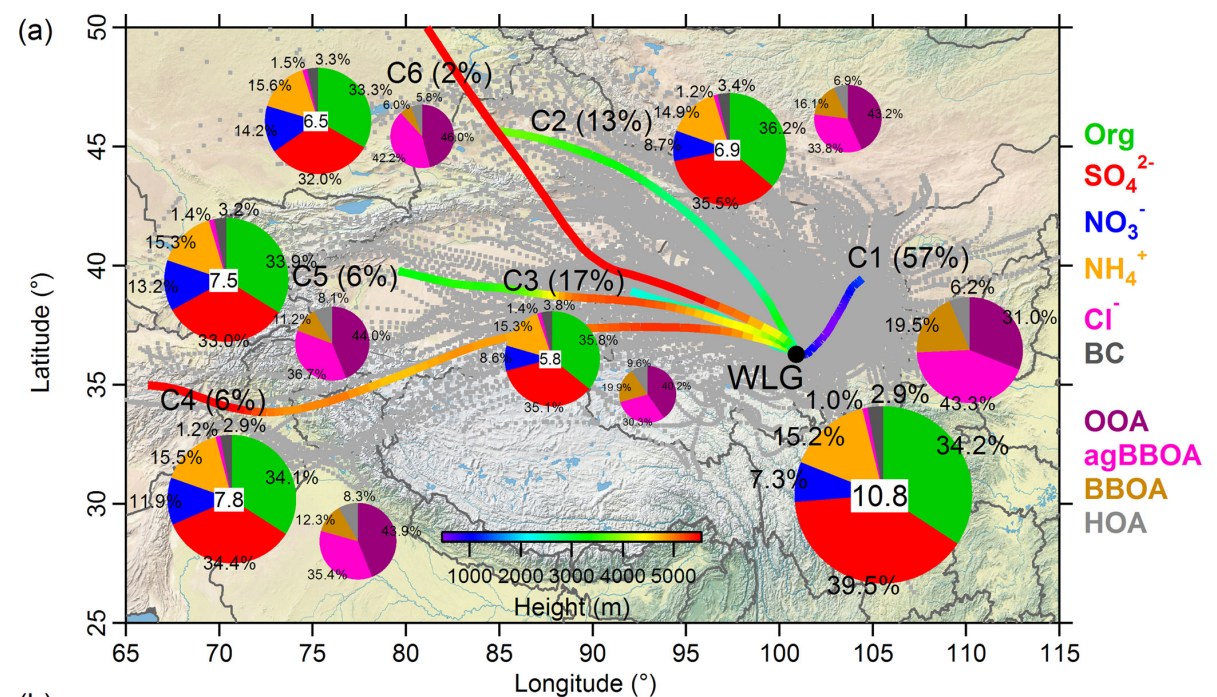

(b)

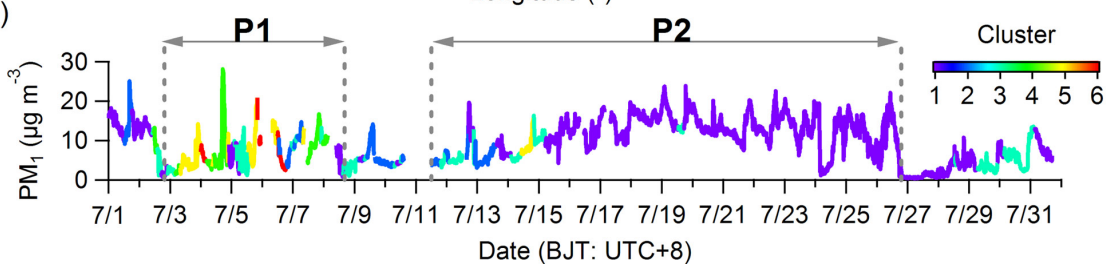

Figure 7. (a) The $72 \mathrm{~h}$ backward air mass trajectories (gray dotted lines) and average trajectory clusters (solid lines colored according to

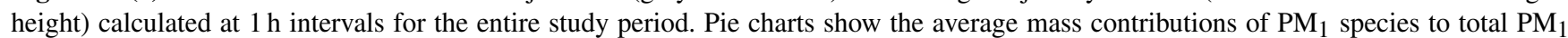
(average $\mathrm{PM}_{1}$ mass values are marked in the center of the pie charts) and OA components to total organics belong to each cluster (areas of pie charts are scaled by the corresponding average mass). (b) Temporal variation of $\mathrm{PM}_{1}$ mass concentration colored by the corresponding cluster name in this study. The markers of P1 and P2 represent two different periods that selected in this study.

components together contributed more than half of the total organics. In addition, obviously enhanced contributions were found for the two biomass-burning-related OA components, particularly for agBBOA, with increasing organic mass, whereas OOA decreased correspondingly (Fig. 6b). For example, BBOA and agBBOA contributed only $\sim 10 \%$ to total organics when OA was less than $1.0 \mu \mathrm{g} \mathrm{m}^{-3}$, whereas the contribution reached up to $70 \%$ with the mass concentration of $\mathrm{OA}$ increasing to $7 \mu \mathrm{g} \mathrm{m} \mathrm{m}^{-3}$. Moreover, the important contribution of agBBOA could also be clearly seen in the temporal variations in Fig. $2 \mathrm{f}$, where agBBOA dominated organics during the relatively polluted periods. All of these suggested that biomass burning emissions from regional transport was the important source for OA at WLG. The triangle plot ( $f 44$ vs. $f 43$ or $f \mathrm{CO}_{2}^{+}$vs. $f \mathrm{C}_{3} \mathrm{H}_{3} \mathrm{O}^{+}$), which has been widely used in AMS studies, was a useful method to characterize the possible evolution mechanism of organic components upon aging in the ambient atmosphere (Ng et al., 2010). As shown in Fig. 4c and d, the majority of data are distributed within the two dashed lines defined as the general triangular space where ambient organic components fall by $\mathrm{Ng}$ et al. (2010). HOA is located at the bottom of the triangle plots, while the two biomass-burning-related components are located in the middle part and OOA in the upper- left corner of the triangle plots, suggesting a possible oxidation pathway from relatively primary components (HOA or BBOA) to secondary components (agBBOA or OOA).

\subsection{Source analysis}

In order to study the dominant sources and explore the influence of regional transport to $\mathrm{PM}_{1}$ mass loading and chemical composition at WLG during summer season, the $72 \mathrm{~h}$ backward air mass trajectories and average clusters at $500 \mathrm{~m}$ above ground level were calculated at $1 \mathrm{~h}$ intervals using the Hybrid Single Particle Lagrangian Integrated Trajectory (HYSPLIT) model (Draxler and Rolph, 2003) and meteorological data from the NOAA Global Data Assimilation System (GDAS). Finally, six air mass clusters were adopted in this study as presented in Fig. 7a.

Air masses from the northeast $(\mathrm{C} 1)$ with the shortest transport distance and lowest height among all the clusters dominated the air mass contribution $(57 \%)$ and had the highest average $\mathrm{PM}_{1}$ mass concentration $\left(10.8 \mu \mathrm{g} \mathrm{m}^{-3}\right)$ during the sampling period, whereas the remaining five clusters $(\mathrm{C} 2-$ C6) were generally from the west or northwest and showed apparently longer transport distances, higher heights and relatively lower mass concentrations $\left(5.8-7.8 \mu \mathrm{g} \mathrm{m}^{-3}\right)$ than $\mathrm{C} 1$. As shown in Fig. 1b, three towns (Haiyan, Huangyuan and 

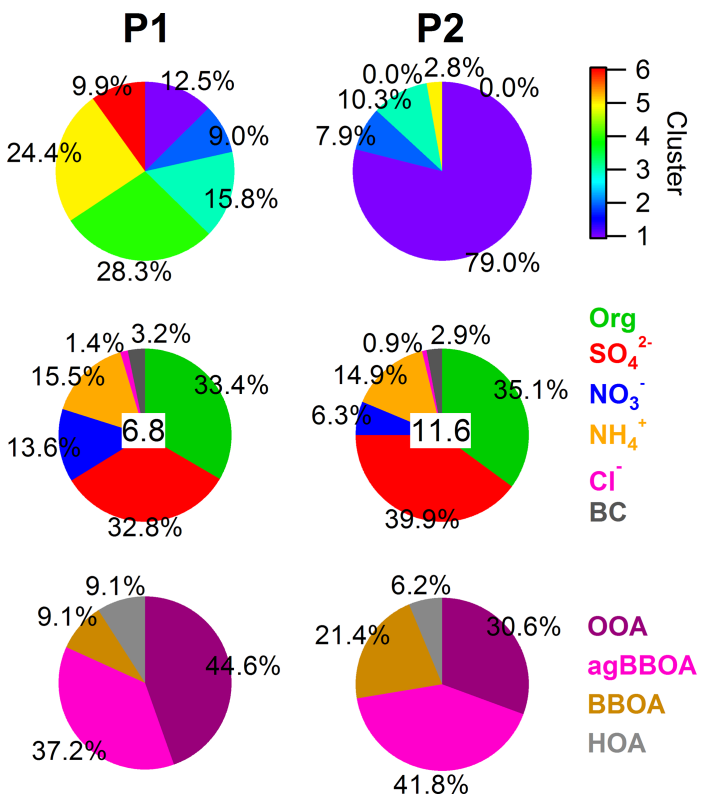

Figure 8. (a) The occurrence frequency of six air mass trajectory clusters, (b) average contributions of $\mathrm{PM}_{1}$ chemical species to total $\mathrm{PM}_{1}$ and (c) average contributions of four organic components to total organics during $\mathrm{P} 1$ and $\mathrm{P} 2$, respectively.

Huangzhong) as well as the capital city (Xining) of Qinghai Province were located to the northeast of WLG within $100 \mathrm{~km}$, leading to relatively dense population and intense industrial activities in these areas compared to those areas to the west of WLG. Therefore, the prevailing air masses with low transport height for $\mathrm{C} 1$ could bring a large amount of surface anthropogenic and industrial pollutants to WLG. This conclusion could further be supported by the significantly different contributions of chemical species during each cluster (Fig. 7a). Specifically, C1 showed higher contribution of sulfate compared to other clusters $(39.5 \%$ vs. $32.0 \%-35.5 \%$ ), which was mainly related to the intense industrial emissions. In addition, OA components for $\mathrm{C} 1$ showed higher contributions from BBOA $(19.5 \%)$ and agBBOA (43.3\%) compared to those for C4 and C5 (12.3\% and $11.2 \%$ for BBOA and $35.4 \%$ and $36.7 \%$ for agBBOA, respectively), whereas much lower contribution of oxidized OOA was found for $\mathrm{C} 1$ than those for $\mathrm{C} 4$ and $\mathrm{C} 5(31.0 \%$ vs. $43.9 \%$ and $44.0 \%$ ), suggesting the relatively fresh of OA for $\mathrm{C} 1$. This phenomenon was more clear for the two distinct periods, $\mathrm{P} 1$ and $\mathrm{P} 2$, as shown in Figs. $7 \mathrm{~b}$ and 8 . Air masses for $\mathrm{P} 2$ were mainly from the northeast $(\mathrm{C} 1 ; 79.0 \%)$ and resulted in higher contributions from sulfate $(39.9 \%$ to total $\mathrm{PM}_{1}$ ) and the two biomass-burning-related OA components (BBOA and agBBOA, $63.2 \%$ to total organics); however, three clusters (C4-C6) from the west with long transport distances dominated P1 and led to significant enhancement of OOA contribution.
Besides the back trajectory analysis, bivariate polar plot analysis was another useful method to give insight into the potential source regions of ambient aerosols, which presents the relationships of mass concentrations of $\mathrm{PM}_{1}$ chemical species with wind conditions (WS and WD) (Fig. S12). All species showed elevated mass concentrations from east, however, with different hotspots for various species, suggesting their probably distinct sources and impacts from regional transport. The three main inorganic species (sulfate, nitrate and ammonium) and aged OOA generally had hotspots from the northeast in accordance with the predominant air masses from the northeast during daytime, which showed more intensive anthropogenic and industrial emissions, whereas chloride, $\mathrm{BC}$ and $\mathrm{BBOA}$ had obvious hotspots from the southeast with wind speed around $10 \mathrm{~m} \mathrm{~s}^{-1}$, which were mainly associated with the possible burning emissions of residents located to the southeast of WLG during nighttime.

\section{Conclusions}

In this study, the highly time resolved physicochemical properties of submicron aerosols were investigated during summer 2017 at a high-altitude background station in the northeastern QTP, using a suite of real-time instruments including HR-ToF-AMS and PAX. The major findings include the following.

The mass concentration of total $\mathrm{PM}_{1}\left(\mathrm{NR}-\mathrm{PM}_{1}+\mathrm{BC}\right)$ varied dynamically between 0.3 and $28.1 \mu \mathrm{g} \mathrm{m}^{-3}$ during this study, with an average $\mathrm{PM}_{1}$ mass loading of 9.1 $( \pm 5.3) \mu \mathrm{g} \mathrm{m}^{-3}$, which was higher than those measured with the Aerodyne AMS at other high-elevation sites in the southern or central QTP. Different from the significant impacts of biomass burning emissions in the southern QTP, sulfate showed a dominant contribution $(38.1 \%)$ at WLG. In addition, the mass contribution of sulfate increased obviously with the increase in $\mathrm{PM}_{1}$ mass loading, indicating the apparently regional transport of sulfate from industrial areas in northwestern China. Correspondingly, $\mathrm{PM}_{1}$ appeared to be slightly acidic throughout this study, mainly related to the enhanced sulfate contribution. All chemical species of NR$\mathrm{PM}_{1}$ peaked at the accumulation mode, suggesting the wellmixed and highly aged aerosol particles at WLG during the sampling period.

OA on average was dominated by $65.7 \%$ of $\mathrm{C}_{x} \mathrm{H}_{y} \mathrm{O}_{z}^{+}$ion fragment, with the average $\mathrm{O} / \mathrm{C}$ ratio of 0.99 and $\mathrm{OM} / \mathrm{OC}$ ratio of 2.44 , indicating its highly aged property at this remote site. PMF analysis performed on the OA HRMS resolved four distinct OA components, including HOA, BBOA, agBBOA and OOA. On average, the two relatively oxidized OAs (OOA and agBBOA) contributed $34.4 \%$ and $40.4 \%$, respectively, while the rest were $18.4 \%$ for BBOA and $6.8 \%$ for HOA. In addition, obvious enhanced contributions were found for the two biomass-burning-related OA components 
with the increasing OA mass, demonstrating that biomass burning emissions from regional transport were the dominant OA source at WLG.

Air masses from the northeast $(\mathrm{C} 1)$ with the shortest transport distance among the six clusters presented dominant contribution $(57 \%)$ and the highest $\mathrm{PM}_{1}$ mass concentration $\left(10.8 \mu \mathrm{g} \mathrm{m}^{-3}\right)$, mainly due to the enhanced contributions of sulfate and biomass-burning-related OA components from the industrial areas in northwestern China. The remaining clusters (C2-C6) from the west or northwest with apparently larger transport distances, however, showed relatively lower mass concentrations and higher OOA contributions than $\mathrm{C} 1$. These source analyses together suggested the distinct aerosol sources and significant impacts of regional transport on aerosol mass loadings and chemical compositions at WLG during summer season.

Data availability. The processed AMS data and meteorological data in this study are available upon request from the corresponding author.

Supplement. The supplement related to this article is available online at: https://doi.org/10.5194/acp-19-7897-2019-supplement.

Author contributions. XHZ analyzed the data and wrote the manuscript. JZX organized the campaign, analyzed data, and wrote the manuscript. SCK and QZ wrote the manuscript. JYS provided supporting data including particulate matter and gaseous species for the study.

Competing interests. The authors declare that they have no conflict of interest.

Special issue statement. This article is part of the special issue "Study of ozone, aerosols and radiation over the Tibetan Plateau (SOAR-TP) (ACP/AMT inter-journal SI)". It is not associated with a conference.

Acknowledgements. The authors thank the Waliguan Baseline Observatory for the logistical support with the field campaign and thank the colleagues for continuing support and discussion.

Financial support. This research has been supported by the National Natural Science Foundation of China (grant no. 41771079 and 41721091), the Key Laboratory of Cryospheric Sciences Scientific Research Foundation (grant no. SKLCS-ZZ-2019), the Strategic Priority Research Program of the Chinese Academy of Sciences, the Pan-Third Pole Environment Study for a Green Silk Road (PanTPE) (grant no. XDA20040501), and the Chinese Academy of Sciences Hundred Talents Program.
Review statement. This paper was edited by Stefania Gilardoni and reviewed by three anonymous referees.

\section{References}

Aiken, A. C., DeCarlo, P. F., Kroll, J. H., Worsnop, D. R., Huffman, J. A., Docherty, K. S., Ulbrich, I. M., Mohr, C., Kimmel, J. R., Sueper, D., Sun, Y., Zhang, Q., Trimborn, A., Northway, M., Ziemann, P. J., Canagaratna, M. R., Onasch, T. B., Alfarra, M. R., Prevot, A. S. H., Dommen, J., Duplissy, J., Metzger, A., Baltensperger, U., and Jimenez, J. L.: $\mathrm{O} / \mathrm{C}$ and $\mathrm{OM} / \mathrm{OC}$ ratios of primary, secondary, and ambient organic aerosols with high-resolution time-of-flight aerosol mass spectrometry, Environ. Sci. Technol., 42, 4478-4485, https://doi.org/10.1021/es703009q, 2008.

Aiken, A. C., Salcedo, D., Cubison, M. J., Huffman, J. A., DeCarlo, P. F., Ulbrich, I. M., Docherty, K. S., Sueper, D., Kimmel, J. R., Worsnop, D. R., Trimborn, A., Northway, M., Stone, E. A., Schauer, J. J., Volkamer, R. M., Fortner, E., de Foy, B., Wang, J., Laskin, A., Shutthanandan, V., Zheng, J., Zhang, R., Gaffney, J., Marley, N. A., Paredes-Miranda, G., Arnott, W. P., Molina, L. T., Sosa, G., and Jimenez, J. L.: Mexico City aerosol analysis during MILAGRO using high resolution aerosol mass spectrometry at the urban supersite (T0) - Part 1: Fine particle composition and organic source apportionment, Atmos. Chem. Phys., 9, 6633-6653, https://doi.org/10.5194/acp-9-6633-2009, 2009.

Alfarra, M. R., Prevot, A. S. H., Szidat, S., Sandradewi, J., Weimer, S., Lanz, V. A., Schreiber, D., Mohr, M., and Baltensperger, U.: Identification of the Mass Spectral Signature of Organic Aerosols from Wood Burning Emissions, Environ. Sci. Technol., 41, 5770-5777, https://doi.org/10.1021/es062289b, 2007.

Canagaratna, M. R., Jayne, J. T., Jimenez, J. L., Allan, J. D., Alfarra, M. R., Zhang, Q., Onasch, T. B., Drewnick, F., Coe, H., Middlebrook, A., Delia, A., Williams, L. R., Trimborn, A. M., Northway, M. J., DeCarlo, P. F., Kolb, C. E., Davidovits, P., and Worsnop, D. R.: Chemical and microphysical characterization of ambient aerosols with the aerodyne aerosol mass spectrometer, Mass Spectrom. Rev., 26, 185-222, https://doi.org/10.1002/mas.20115, 2007.

Canagaratna, M. R., Jimenez, J. L., Kroll, J. H., Chen, Q., Kessler, S. H., Massoli, P., Hildebrandt Ruiz, L., Fortner, E., Williams, L. R., Wilson, K. R., Surratt, J. D., Donahue, N. M., Jayne, J. T., and Worsnop, D. R.: Elemental ratio measurements of organic compounds using aerosol mass spectrometry: characterization, improved calibration, and implications, Atmos. Chem. Phys., 15, 253-272, https://doi.org/10.5194/acp-15-253-2015, 2015.

Crippa, M., DeCarlo, P. F., Slowik, J. G., Mohr, C., Heringa, M. F., Chirico, R., Poulain, L., Freutel, F., Sciare, J., Cozic, J., Di Marco, C. F., Elsasser, M., Nicolas, J. B., Marchand, N., Abidi, E., Wiedensohler, A., Drewnick, F., Schneider, J., Borrmann, S., Nemitz, E., Zimmermann, R., Jaffrezo, J.-L., Prévôt, A. S. H., and Baltensperger, U.: Wintertime aerosol chemical composition and source apportionment of the organic fraction in the metropolitan area of Paris, Atmos. Chem. Phys., 13, 961-981, https://doi.org/10.5194/acp-13-961-2013, 2013.

Cubison, M. J., Ortega, A. M., Hayes, P. L., Farmer, D. K., Day, D., Lechner, M. J., Brune, W. H., Apel, E., Diskin, G. S., Fisher, J. A., Fuelberg, H. E., Hecobian, A., Knapp, D. J., Mikoviny, 
T., Riemer, D., Sachse, G. W., Sessions, W., Weber, R. J., Weinheimer, A. J., Wisthaler, A., and Jimenez, J. L.: Effects of aging on organic aerosol from open biomass burning smoke in aircraft and laboratory studies, Atmos. Chem. Phys., 11, 12049-12064, https://doi.org/10.5194/acp-11-12049-2011, 2011.

DeCarlo, P. F., Kimmel, J. R., Trimborn, A., Northway, M. J., Jayne, J. T., Aiken, A. C., Gonin, M., Fuhrer, K., Horvath, T., Docherty, K. S., Worsnop, D. R., and Jimenez, J. L.: Field-Deployable, High-Resolution, Time-ofFlight Aerosol Mass Spectrometer, Anal. Chem., 78, 8281-8289, https://doi.org/10.1021/ac061249n, 2006.

Draxler, R. R. and Rolph, G. D.: HYSPLIT (HYbrid Single-Particle Lagrangian Integrated Trajectory) model access via NOAA ARL READY website NOAA Air Resources Laboratory, Silver Spring, MD, USA, available at: http://www.arl.noaa.gov/ready/ hysplit4.html (last access: 5 June 2019), 2003.

Du, W., Sun, Y. L., Xu, Y. S., Jiang, Q., Wang, Q. Q., Yang, W., Wang, F., Bai, Z. P., Zhao, X. D., and Yang, Y. C.: Chemical characterization of submicron aerosol and particle growth events at a national background site (3295 ma.s.1.) on the Tibetan Plateau, Atmos. Chem. Phys., 15, 10811-10824, https://doi.org/10.5194/acp-15-10811-2015, 2015.

Elser, M., Huang, R.-J., Wolf, R., Slowik, J. G., Wang, Q., Canonaco, F., Li, G., Bozzetti, C., Daellenbach, K. R., Huang, Y., Zhang, R., Li, Z., Cao, J., Baltensperger, U., El-Haddad, I., and Prévôt, A. S. H.: New insights into $\mathrm{PM}_{2.5}$ chemical composition and sources in two major cities in China during extreme haze events using aerosol mass spectrometry, Atmos. Chem. Phys., 16, 3207-3225, https://doi.org/10.5194/acp-16-3207-2016, 2016.

Engling, G., Zhang, Y. N., Chan, C. Y., Sang, X. F., Lin, M., Ho, K. F., Li, Y. S., Lin, C. Y., and Lee, J. J.: Characterization and sources of aerosol particles over the southeastern Tibetan Plateau during the Southeast Asia biomass-burning season, Tellus B, 63, 117-128, https://doi.org/10.1111/j.1600-0889.2010.00512.x, 2011.

He, L.-Y., Lin, Y., Huang, X.-F., Guo, S., Xue, L., Su, Q., Hu, M., Luan, S.-J., and Zhang, Y.-H.: Characterization of highresolution aerosol mass spectra of primary organic aerosol emissions from Chinese cooking and biomass burning, Atmos. Chem. Phys., 10, 11535-11543, https://doi.org/10.5194/acp-10-115352010, 2010.

Heald, C. L., Kroll, J. H., Jimenez, J. L., Docherty, K. S., DeCarlo, P. F., Aiken, A. C., Chen, Q., Martin, S. T., Farmer, D. K., and Artaxo, P.: A simplified description of the evolution of organic aerosol composition in the atmosphere, Geophys. Res. Lett., 37, L08803, https://doi.org/10.1029/2010g1042737, 2010.

Hu, W., Hu, M., Hu, W.-W., Zheng, J., Chen, C., Wu, Y., and Guo, S.: Seasonal variations in high time-resolved chemical compositions, sources, and evolution of atmospheric submicron aerosols in the megacity Beijing, Atmos. Chem. Phys., 17, 9979-10000, https://doi.org/10.5194/acp-17-9979-2017, 2017.

Hu, W. W., Hu, M., Hu, W., Jimenez, J. L., Yuan, B., Chen, W., Wang, M., Wu, Y., Chen, C., Wang, Z., Peng, J., Zeng, L., and Shao, M.: Chemical composition, sources, and aging process of submicron aerosols in Beijing: Contrast between summer and winter, J. Geophys. Res.-Atmos., 121, 1955-1977, https://doi.org/10.1002/2015jd024020, 2016.

Huang, X.-F., He, L.-Y., Hu, M., Canagaratna, M. R., Kroll, J. H., Ng, N. L., Zhang, Y.-H., Lin, Y., Xue, L., Sun, T.-
L., Liu, X.-G., Shao, M., Jayne, J. T., and Worsnop, D. R.: Characterization of submicron aerosols at a rural site in Pearl River Delta of China using an Aerodyne High-Resolution Aerosol Mass Spectrometer, Atmos. Chem. Phys., 11, 18651877, https://doi.org/10.5194/acp-11-1865-2011, 2011.

Jayne, J. T., Leard, D. C., Zhang, X. F., Davidovits, P., Smith, K. A., Kolb, C. E., and Worsnop, D. R.: Development of an aerosol mass spectrometer for size and composition analysis of submicron particles, Aerosol Sci. Technol., 33, 49-70, https://doi.org/10.1080/027868200410840, 2000.

Jimenez, J. L., Jayne, J. T., Shi, Q., Kolb, C. E., Worsnop, D. R., Yourshaw, I., Seinfeld, J. H., Flagan, R. C., Zhang, X., Smith, K. A., Morris, J. W., and Davidovits, P.: Ambient aerosol sampling using the Aerodyne Aerosol Mass Spectrometer, J. Geophys. Res., 108, 8425, https://doi.org/10.1029/2001jd001213, 2003.

Kang, S., Xu, Y., You, Q., Flügel, W.-A., Pepin, N., and Yao, T.: Review of climate and cryospheric change in the Tibetan Plateau, Environ. Res. Lett., 5, 015101, https://doi.org/10.1088/17489326/5/1/015101, 2010.

Li, C., Bosch, C., Kang, S., Andersson, A., Chen, P., Zhang, Q., Cong, Z., Chen, B., Qin, D., and Gustafsson, O.: Sources of black carbon to the Himalayan-Tibetan Plateau glaciers, Nat. Commun., 7, 12574, https://doi.org/10.1038/ncomms12574, 2016.

Li, J., Wang, G., Wang, X., Cao, J., Sun, T., Cheng, C., Meng, J., $\mathrm{Hu}, \mathrm{T}$., and Liu, S.: Abundance, composition and source of atmospheric $\mathrm{PM}_{2.5}$ at a remote site in the Tibetan Plateau, China, Tellus B, 65, 20281, https://doi.org/10.3402/tellusb.v65i0.20281, 2013.

Li, Y. J., Sun, Y., Zhang, Q., Li, X., Li, M., Zhou, Z., and Chan, C. K.: Real-time chemical characterization of atmospheric particulate matter in China: A review, Atmos. Environ., 158, 270-304, https://doi.org/10.1016/j.atmosenv.2017.02.027, 2017.

Lu, Z., Zhang, Q., and Streets, D. G.: Sulfur dioxide and primary carbonaceous aerosol emissions in China and India, 1996-2010, Atmos. Chem. Phys., 11, 9839-9864, https://doi.org/10.5194/acp-11-9839-2011, 2011.

Lüthi, Z. L., Škerlak, B., Kim, S.-W., Lauer, A., Mues, A., Rupakheti, M., and Kang, S.: Atmospheric brown clouds reach the Tibetan Plateau by crossing the Himalayas, Atmos. Chem. Phys., 15, 6007-6021, https://doi.org/10.5194/acp-156007-2015, 2015.

Middlebrook, A. M., Bahreini, R., Jimenez, J. L., and Canagaratna, M. R.: Evaluation of Composition-Dependent Collection Efficiencies for the Aerodyne Aerosol Mass Spectrometer using Field Data, Aerosol Sci. Technol., 46, 258-271, https://doi.org/10.1080/02786826.2011.620041, 2012.

Mohr, C., DeCarlo, P. F., Heringa, M. F., Chirico, R., Slowik, J. G., Richter, R., Reche, C., Alastuey, A., Querol, X., Seco, R., Peñuelas, J., Jiménez, J. L., Crippa, M., Zimmermann, R., Baltensperger, U., and Prévôt, A. S. H.: Identification and quantification of organic aerosol from cooking and other sources in Barcelona using aerosol mass spectrometer data, Atmos. Chem. Phys., 12, 1649-1665, https://doi.org/10.5194/acp-121649-2012, 2012.

Ng, N. L., Canagaratna, M. R., Zhang, Q., Jimenez, J. L., Tian, J., Ulbrich, I. M., Kroll, J. H., Docherty, K. S., Chhabra, P. S., Bahreini, R., Murphy, S. M., Seinfeld, J. H., Hildebrandt, L., Donahue, N. M., DeCarlo, P. F., Lanz, V. A., Prévôt, A. S. H., Dinar, E., Rudich, Y., and Worsnop, D. R.: Organic aerosol 
components observed in Northern Hemispheric datasets from Aerosol Mass Spectrometry, Atmos. Chem. Phys., 10, 46254641, https://doi.org/10.5194/acp-10-4625-2010, 2010.

Ng, N. L., Canagaratna, M. R., Jimenez, J. L., Zhang, Q., Ulbrich, I. M., and Worsnop, D. R.: Real-time methods for estimating organic component mass concentrations from aerosol mass spectrometer data, Environ. Sci. Technol., 45, 910-916, https://doi.org/10.1021/es102951k, 2011.

Paatero, P. and Tapper, U.: Positive matrix factorization: A non-negative factor model with optimal utilization of error estimates of data values, Environmetrics, 5, 111-126, https://doi.org/10.1002/env.3170050203, 1994.

Qian, Y., Flanner, M. G., Leung, L. R., and Wang, W.: Sensitivity studies on the impacts of Tibetan Plateau snowpack pollution on the Asian hydrological cycle and monsoon climate, Atmos. Chem. Phys., 11, 1929-1948, https://doi.org/10.5194/acp11-1929-2011, 2011.

Sun, Y., Du, W., Fu, P., Wang, Q., Li, J., Ge, X., Zhang, Q., Zhu, C., Ren, L., Xu, W., Zhao, J., Han, T., Worsnop, D. R., and Wang, Z.: Primary and secondary aerosols in Beijing in winter: sources, variations and processes, Atmos. Chem. Phys., 16, 8309-8329, https://doi.org/10.5194/acp-16-8309-2016, 2016.

Sun, Y.-L., Zhang, Q., Schwab, J. J., Demerjian, K. L., Chen, W.N., Bae, M.-S., Hung, H.-M., Hogrefe, O., Frank, B., Rattigan, O. V., and Lin, Y.-C.: Characterization of the sources and processes of organic and inorganic aerosols in New York city with a high-resolution time-of-flight aerosol mass apectrometer, Atmos. Chem. Phys., 11, 1581-1602, https://doi.org/10.5194/acp11-1581-2011, 2011.

Ulbrich, I. M., Canagaratna, M. R., Zhang, Q., Worsnop, D. R., and Jimenez, J. L.: Interpretation of organic components from Positive Matrix Factorization of aerosol mass spectrometric data, Atmos. Chem. Phys., 9, 2891-2918, https://doi.org/10.5194/acp-92891-2009, 2009.

van der A, R. J., Mijling, B., Ding, J., Koukouli, M. E., Liu, F., Li, Q., Mao, H., and Theys, N.: Cleaning up the air: effectiveness of air quality policy for $\mathrm{SO}_{2}$ and $\mathrm{NO}_{x}$ emissions in China, Atmos. Chem. Phys., 17, 1775-1789, https://doi.org/10.5194/acp17-1775-2017, 2017

Wang, J., Zhang, Q., Chen, M., Collier, S., Zhou, S., Ge, X., Xu, J., Shi, J., Xie, C., Hu, J., Ge, S., Sun, Y., and Coe, H.: First Chemical Characterization of Refractory Black Carbon Aerosols and Associated Coatings over the Tibetan Plateau (4730 m a.s.1), Environ. Sci. Technol., 51, 14072-14082, https://doi.org/10.1021/acs.est.7b03973, 2017.

Xia, X., Zong, X., Cong, Z., Chen, H., Kang, S., and Wang, P.: Baseline continental aerosol over the central Tibetan plateau and a case study of aerosol transport from South Asia, Atmos. Environ., 45, 7370-7378, https://doi.org/10.1016/j.atmosenv.2011.07.067, 2011.

Xu, B., Cao, J., Hansen, J., Yao, T., Joswia, D. R., Wang, N., Wu, G., Wang, M., Zhao, H., Yang, W., Liu, X., and He, J.: Black soot and the survival of Tibetan glaciers, P. Natl. Acad. Sci. USA, 106, 22114-22118, https://doi.org/10.1073/pnas.0910444106, 2009.

Xu, J., Wang, Z., Yu, G., Sun, W., Qin, X., Ren, J., and Qin, D.: Seasonal and diurnal variations in aerosol concentrations at a high-altitude site on the northern boundary of Qinghai-Xizang Plateau, Atmos. Res., 120-121, 240-248, https://doi.org/10.1016/j.atmosres.2012.08.022, 2013.
Xu, J., Wang, Z., Yu, G., Qin, X., Ren, J., and Qin, D.: Characteristics of water soluble ionic species in fine particles from a high altitude site on the northern boundary of Tibetan Plateau: Mixture of mineral dust and anthropogenic aerosol, Atmos. Res., 143, 4356, https://doi.org/10.1016/j.atmosres.2014.01.018, 2014a.

Xu, J., Zhang, Q., Chen, M., Ge, X., Ren, J., and Qin, D.: Chemical composition, sources, and processes of urban aerosols during summertime in northwest China: insights from high-resolution aerosol mass spectrometry, Atmos. Chem. Phys., 14, 1259312611, https://doi.org/10.5194/acp-14-12593-2014, 2014b.

Xu, J., Shi, J., Zhang, Q., Ge, X., Canonaco, F., Prévôt, A. S. H., Vonwiller, M., Szidat, S., Ge, J., Ma, J., An, Y., Kang, S., and Qin, D.: Wintertime organic and inorganic aerosols in Lanzhou, China: sources, processes, and comparison with the results during summer, Atmos. Chem. Phys., 16, 14937-14957, https://doi.org/10.5194/acp-16-14937-2016, 2016.

Xu, J., Zhang, Q., Shi, J., Ge, X., Xie, C., Wang, J., Kang, S., Zhang, R., and Wang, Y.: Chemical characteristics of submicron particles at the central Tibetan Plateau: insights from aerosol mass spectrometry, Atmos. Chem. Phys., 18, 427-443, https://doi.org/10.5194/acp-18-427-2018, 2018.

Xu, J. Z., Zhang, Q., Wang, Z. B., Yu, G. M., Ge, X. L., and Qin, $\mathrm{X}$.: Chemical composition and size distribution of summertime $\mathrm{PM}_{2.5}$ at a high altitude remote location in the northeast of the Qinghai-Xizang (Tibet) Plateau: insights into aerosol sources and processing in free troposphere, Atmos. Chem. Phys., 15, 5069-5081, https://doi.org/10.5194/acp-15-5069-2015, 2015.

Xue, L. K., Wang, T., Guo, H., Blake, D. R., Tang, J., Zhang, X. C., Saunders, S. M., and Wang, W. X.: Sources and photochemistry of volatile organic compounds in the remote atmosphere of western China: results from the Mt. Waliguan Observatory, Atmos. Chem. Phys., 13, 8551-8567, https://doi.org/10.5194/acp13-8551-2013, 2013.

Yang, K., Wu, H., Qin, J., Lin, C., Tang, W., and Chen, Y.: Recent climate changes over the Tibetan Plateau and their impacts on energy and water cycle: A review, Global Planet. Change, 112, 79-91, https://doi.org/10.1016/j.gloplacha.2013.12.001, 2014.

Yao, T., Thompson, L., Mosbrugger, V., Zhang, F., Ma, Y., Luo, T., Xu, B., Yang, X., Joswiak, D. R., Wang, W., Joswiak, M. E., Devkota, L. P., Tayal, S., Jilani, R., and Fayziev, R.: Third Pole Environment (TPE), Environmental Development, 3, 5264, https://doi.org/10.1016/j.envdev.2012.04.002, 2012.

Zhang, N., Cao, J., Liu, S., Zhao, Z., Xu, H., and Xiao, S.: Chemical composition and sources of $\mathrm{PM}_{2.5}$ and TSP collected at Qinghai Lake during summertime, Atmos. Res., 138, 213-222, https://doi.org/10.1016/j.atmosres.2013.11.016, 2014.

Zhang, Q., Worsnop, D. R., Canagaratna, M. R., and Jimenez, J. L.: Hydrocarbon-like and oxygenated organic aerosols in Pittsburgh: insights into sources and processes of organic aerosols, Atmos. Chem. Phys., 5, 3289-3311, https://doi.org/10.5194/acp-5-32892005, 2005.

Zhang, Q., Jimenez, J. L., Worsnop, D. R., and Canagaratna, M.: A case study of urban particle acidity and its influence on secondary organic aerosol, Environ. Sci. Technol., 41, 3213-3219, https://doi.org/10.1021/es061812j, 2007.

Zhang, Q., Jimenez, J. L., Canagaratna, M. R., Ulbrich, I. M., Ng, N. L., Worsnop, D. R., and Sun, Y.: Understanding atmospheric organic aerosols via factor analysis of aerosol mass 
spectrometry: a review, Anal. Bioanal. Chem., 401, 3045-3067, https://doi.org/10.1007/s00216-011-5355-y, 2011.

Zhang, R., Wang, Y., He, Q., Chen, L., Zhang, Y., Qu, H., Smeltzer, C., Li, J., Alvarado, L. M. A., Vrekoussis, M., Richter, A., Wittrock, F., and Burrows, J. P.: Enhanced trans-Himalaya pollution transport to the Tibetan Plateau by cut-off low systems, Atmos. Chem. Phys., 17, 3083-3095, https://doi.org/10.5194/acp17-3083-2017, 2017.

Zhang, X., Xu, J., Kang, S., Liu, Y., and Zhang, Q.: Chemical characterization of long-range transport biomass burning emissions to the Himalayas: insights from high-resolution aerosol mass spectrometry, Atmos. Chem. Phys., 18, 4617-4638, https://doi.org/10.5194/acp-18-4617-2018, 2018.

Zhang, Y. J., Tang, L. L., Wang, Z., Yu, H. X., Sun, Y. L., Liu, D., Qin, W., Canonaco, F., Prévôt, A. S. H., Zhang, H. L., and Zhou, H. C.: Insights into characteristics, sources, and evolution of submicron aerosols during harvest seasons in the Yangtze River delta region, China, Atmos. Chem. Phys., 15, 1331-1349, https://doi.org/10.5194/acp-15-1331-2015, 2015.
Zheng, J., Hu, M., Du, Z., Shang, D., Gong, Z., Qin, Y., Fang, J., Gu, F., Li, M., Peng, J., Li, J., Zhang, Y., Huang, X., He, L., $\mathrm{Wu}, \mathrm{Y}$., and Guo, S.: Influence of biomass burning from South Asia at a high-altitude mountain receptor site in China, Atmos. Chem. Phys., 17, 6853-6864, https://doi.org/10.5194/acp17-6853-2017, 2017.

Zhou, S., Collier, S., Jaffe, D. A., Briggs, N. L., Hee, J., Sedlacek III, A. J., Kleinman, L., Onasch, T. B., and Zhang, Q.: Regional influence of wildfires on aerosol chemistry in the western US and insights into atmospheric aging of biomass burning organic aerosol, Atmos. Chem. Phys., 17, 2477-2493, https://doi.org/10.5194/acp-17-2477-2017, 2017. 